IZA DP No. 5504

Institutions and Entry:

A Cross-Regional Analysis in Russia

Randolph Luca Bruno

Maria Bytchkova

Saul Estrin

February 2011 


\title{
Institutions and Entry: A Cross-Regional Analysis in Russia
}

\author{
Randolph Luca Bruno \\ University of Birmingham, \\ fRDB and IZA \\ Maria Bytchkova \\ London School of Economics \\ Saul Estrin \\ London School of Economics, \\ CEPR and IZA
}

\section{Discussion Paper No. 5504 \\ February 2011}

\author{
IZA \\ P.O. Box 7240 \\ 53072 Bonn \\ Germany \\ Phone: +49-228-3894-0 \\ Fax: +49-228-3894-180 \\ E-mail: iza@iza.org
}

Any opinions expressed here are those of the author(s) and not those of IZA. Research published in this series may include views on policy, but the institute itself takes no institutional policy positions.

The Institute for the Study of Labor (IZA) in Bonn is a local and virtual international research center and a place of communication between science, politics and business. IZA is an independent nonprofit organization supported by Deutsche Post Foundation. The center is associated with the University of Bonn and offers a stimulating research environment through its international network, workshops and conferences, data service, project support, research visits and doctoral program. IZA engages in (i) original and internationally competitive research in all fields of labor economics, (ii) development of policy concepts, and (iii) dissemination of research results and concepts to the interested public.

IZA Discussion Papers often represent preliminary work and are circulated to encourage discussion. Citation of such a paper should account for its provisional character. A revised version may be available directly from the author. 
IZA Discussion Paper No. 5504

February 2011

\begin{abstract}
Institutions and Entry: A Cross-Regional Analysis in Russia*

We analyse a micro-panel data set to investigate the effect of regional institutional environment and economic factors on Russian new firm entry rates across time, industries and regions. The paper builds on novel databases and exploits inter-regional variation in a large number of institutional variables. We find entry rates across industries in Russia are not especially low by international standards and are correlated with entry rates in developed market economies, as well as with institutional environment and firm size. Furthermore, industries that, for scale or technological reasons, are characterised by higher entry rates experience lower entry within regions affected subject to political change. A higher level of democracy enhances entry rates for small sized firms but reduces them for medium or large ones.
\end{abstract}

JEL Classification: D22, L26, P31

Keywords: entry rate, institutions, democracy

Corresponding author:

Saul Estrin

Department of Management

London School of Economics

Houghton Street

London WC2A 2AE

United Kingdom

E-mail: S.Estrin@Ise.ac.uk

\footnotetext{
* The authors would like to thank Will Bartlett, Daniel Berkowitz, Nauro Campos, Richard Connolly, Padma Desai, Christopher Gerry, Francesca Lotti, Laura Magazzini, Svetlana Makarova, Tomasz Mickiewicz, Eugene Nivorozhkin and Thomas F. Remington for fruitful comments. Versions of this paper have been presented at the London Business School, CIFREM (University of Trento), SSEES (University College of London), the EACES Conference (Higher School of Economics, Moscow), the International OECD-UNDP Conference (School of Local Development, Trento), the Italian Congress of Econometrics and Empirical Economics (Univ. Marche, Ancona) and the COST Workshop "Firm-Level Data Analysis in Transition and Developing Economies", University of Edinburgh, Scotland, CEELBAS (St. Antony's College, University of Oxford), and at the University of Birmingham. We would like to thank Tanja Lipiainen and Michael Rochlitz for excellent research assistance. Any remaining errors are our own.
} 


\section{INTRODUCTION}

The process of entry of new firms is an important element in the dynamics of market economies, Caves (1998), Bertelsman, Hattiwanger, and Scarpetta (2004). As a crucial aspect of the "creative destruction" process, new firm entry helps to transfer resources from low to high productivity activities and underlies competitive pressures dissipating monopoly rents, Bartelsman, Scarpetta, and Schivardi (2003). From the entrepreneurial perspective, new firm entry may also be the source of innovative processes and products as well as being a key mechanism in their dissemination, Audretsch and Acs (1991). These factors are significant in both developed and developing economies, where new firm entry may also play a central role in narrowing the gap to the technological frontier, Hausman and Rodrik (2003). Entry of new firms is not uniformly beneficial however; Chamberlain's (1956) model of monopolistic competition highlighted the welfare consequences of excessive entry generating excess productive capacity. In imperfect market structures the dangers of insufficient new firm entry seem likely to be more significant than those of excessive entry because the strategic interest of incumbents is to restrict entry. This argument is strengthened in developing economies where there are too few enterprises, Tybout (2000), and entry barriers may be even higher because the weakness of institutions may enhance the market power of incumbents, Djankov, La Porta, Lopez-de-Silanes, and Shleifer (2002), with harmful implications for welfare, Benerjee and Ghatak (2005).

Previous studies, Djankov, La Porta, Lopez-de-Silanes, and Shleifer (2002), Klapper, Laeven, and Rajan (2006), have analysed cross country heterogeneity in entry rates and hypothesised a link with the domestic institutional context. These studies, however, could only partially control for macroeconomic policy differences, trading regimes and numerous other country specific factors. To address this problem, we analyse the impact of institutional quality on the rate of entry in a single emerging 
market; that of Russia. By investigating firm entry on a regional level, we control for the impact of macroeconomic policies and we exploit the regional fragmentation and internal institutional variation of a huge economy to address the problem of omitted variables, Shleifer and Treisman (2005). Our paper therefore contributes to the debate about the impact of institutions on new firm entry by cross-regional crossindustrial entry rates within a single economy. We concentrate on regional economic heterogeneity thereby building on Berkowitz and DeJong (2005a) who show that Russian regional entrepreneurial activity is significantly associated with subsequent growth.

The Russian context provides a natural quasi-experiment in addressing the question of how institutions influence new firm entry. This is because Russia followed a regionally differentiated process of transition to a market economy after the demise of the Soviet Union in 1991. In some regions, market oriented reforms were introduced and implemented rapidly, in others more slowly, and in some hardly at all. We have constructed a data set which charts political and institutional change over time, and we seek to relate developments in firm entry rates by industry and region to prior political changes associated with the timing of elections and the character of the results. In so doing, we build on ideas of Acemoglu and Johnson (2005) that links security of property rights to democracy.

Russia is a federation of states and sub-units and, whilst much of the formal regulatory and institutional framework is common across all regions, control over significant aspects is decentralised. The constitution gives the central government exclusive authority in regulation of foreign trade, legal framework of a single market as well as over financial, currency and customs regulations, OECD (2002). However, there remains great diversity between Russian regions in most other aspects of the 
institutional and political environment and this allows us to explore the impact of institutional variation on entry rates in a novel way.

We build on recent developments in the literature in analysing of inter-regional entry barriers and institutional variation, addressing the issue of economic barriers to entry by exploiting the concept of "natural entry rates", Klapper, Laeven, and Rajan (2006). We use the rate of entry by industry in advanced Western countries as a proxy for the "natural" entry propensity in each region, reflecting inherent technological barriers in that industry caused, for example, by economies of scale or organisational efficiencies gained by incumbents from their experience. We are assuming that the rank ordering of entry in developed economies corresponds to the rank ordering of natural barriers across industries. We undertake our empirical work by combining three major data sources; a huge new comprehensive longitudinal enterprise data set, ORBIS (BvD Copyright), combined with two new sources of information concerning institutions at the regional level. The first concerns political stability and turnover in the regions and has been collected from primary sources in Russia for this study and the second includes both data on regional political and economic openness, McFaul, Petrov, and Ryabov (2004).

The ORBIS dataset is sufficiently comprehensive to allow us to measure entry at the date of incorporation of the firm, rather than the more common but less satisfactory proxy of the date when the firm enters the dataset afresh, Dunne, Roberts, and Samuelson (1989). It also includes the smallest firms, while most studies of entry focus on firms employing more than 50 workers. Much entry takes place in firms with fewer than 50 workers, and these are likely to be particularly sensitive to variation in institutional quality, Aidis, Estrin, and Mickiewicz (2008). However, since entry may also be in part a process of entrepreneurs learning about future profitability, Jovanovic (1982), inclusion of smaller firms also increases the noise and we therefore include 
estimates which control for firm size1. We use difference in difference methods to explain inter-regional entry rates in terms of natural entry rates and institutional variation by region.

We find that entry rates in Russia are not especially low on average, despite deficiencies in the formal institutional environment. Even so, our results provide evidence that regional variation in institutional quality impacts on entry rates relative to the levels that would pertain in Western economies. However, In particular, political uncertainty has a disproportionately large negative effect on entry rates in industries in which the barriers to entry are lower. Thus, if we consider regions across Russia, industries that are characterised by higher entry rates in Western economies experience lower entry in regions with greater political discontinuity. Higher levels of democracy are found to increase entry rates but only for small sized firms. In fact, greater reliance on democratic institutions is found to reduce entry rates for medium and large firms across Russian regions.

The paper is organised as follows: in the second section, we briefly review the literature on entry and institutions; in the third section, the data set is described and the rate of entry is reported across regions, industry and time; section four is dedicated to the empirical strategy and section five to regression results; we draw our main conclusions in section six.

\section{LITERATURE}

The literature on economic development has recently begun to recognise the importance of institutions. There is a growing theoretical and empirical body of work investigating the role of institutions in explaining differences in cross-country

\footnotetext{
1 The dynamic of firm growth might well be size dependent, see Jovanovic (1982), and therefore this might lead to different size-varying natural entry rates. This will be taken into account in the estimation strategy of section four.
} 
economic growth. There are at least two areas in which this literature could usefully be extended. The first is primarily empirical; there are a large number of institutions that can potentially affect growth but these are often difficult to measure; may rely on subjective valuations; and can suffer from endogeneity and multicollinearity. Second, it is hard to isolate the country specific effects from institutional ones.

A common approach to conceptualising institutions emphasizes technical barriers and market supporting institutions, such as availability of credit (narrow institutions) as an important factor influencing economic growth. Increasingly, however, an understanding is emerging that broader governance institutions affect interactions across a series of business, social and political activities and influence economic growth, Acemoglu and Johnson (2005). The view that governance institutions are important for growth has been accepted by international organisations such as the World Bank, IMF and the UN. Indeed, they sometimes provide loans conditional on the introduction of 'good governance' institutions. These institutions can take different form and are aimed at two outcomes - increasing the transparency of decision making and input into policy-making from the general population. These institutions are increasingly seen as important for promoting economic growth.

The literature on new firm entry usually starts from the notion of barriers to entry; a cost for a new entrant which is not borne by the incumbent, Bain (1968), Stigler (1968), and which therefore generates rents for incumbents, Gilbert (1989). The main barriers to entry are often identified empirically to include economies of scale, learning curve advantages, product differentiation and the absolute cost advantages of established firms. A considerable literature has emerged to analyse these phenomena in a strategic and multi-firm setting, e.g. Dixit (1979), Dixit (1981), Aghion and Bolton (1987), Gilbert and Vives (1986), Carlton (2004). The models have also been widely tested on developed economy data, e.g. Orr (1974), Dunne, Roberts, 
and Samuelson (1989), Geroski (1991), Caves (1998) on the basis of equations linking entry rates to measures of, for example, scale economies, sunk costs, market structure and a variety of additional variables.

Decisions by entrepreneurs to enter a market can be viewed as depending on estimated future profits from the venture and secure access to these profits, or the likelihood to lose them, Casson (2005). The industrial organization literature suggests future profits depend on the industry into which the entrepreneur enters, including its technological characteristics, market structure and the strategic interactions of the incumbents. The quality of institutions affects both the return and the riskiness of investment, including the possibility of expropriation via corruption or political turmoil, Rodrik, Subramanian, and Trebbi (2004). Thus, the character of institutional arrangements affects the costs of setting up and running a business, as well as the likelihood of profits being expropriated by other actors. While, institutional variation in developed economies with respect to factors influencing entry is limited, heterogeneity can be much greater in emerging markets. These are often captured by formal indicators of institutional quality. Djankov, La Porta, Lopez-de-Silanes, and Shleifer (2002) have established that there is considerable variation in the regulations governing new firm entry and these are correlated with both entry rates and with corruption. Thus Djankov, La Porta, Lopez-de-Silanes, and Shleifer (2002) report data on regulations of entry (start-ups) in 85 countries and find that there is a positive relationship between the size of informal economy (in turn highly correlated with corruption), and the burden of the entry regulations, measured by the number of procedures, time and cost of starting a firm.

But informal factors are also important, though harder to measure. De Soto's (1990) analysis of entry in developing countries stresses the inter-relationship between formal and informal barriers, with higher formal levels of regulation implying greater 
corruption and informal barriers as well. Tybout (2000) points out that in less developed countries, the cost of entry varies with firm size and prevalence of shadow economy in a specific sector. In such countries, antitrust enforcement is often weak because large firms lobby legislative bodies to restrain the entry of new firms, and to strengthen the incumbents' power. The judicial system underlying formal institutions is not working in a vacuum. Formal business licensing and labour law constraints can be buttressed by informal processes such as embedded social norms and informal institutions (networks, shared business practices, etc.); informal networks can also offset to some extent the problems generated by weaknesses in the formal environment, Estrin and Prevezer (2010). Weak legal and institutional environments raise the cost of doing business, for example the costs of enforcing contracts, and are often associated with higher level of corruption, Friedman, Johnson, Kaufmann, and Zoido-Lobaton (2000). Importantly, these additional costs have the characteristic of entry barriers, bearing more heavily on entrants than incumbents who have developed expertise in operating in this environment. Hence the literature suggests that poor institutional environments are likely to enhance the advantages to incumbents yielded by higher levels of regulation.

The empirical evidence is limited but supports the view that formal barriers have a negative effect on entry. One of the most important papers is by Klapper, Laeven, and Rajan (2006) who by exploiting a difference in difference approach find that regulations hinder entry, notably for those which are in naturally "high entry" industries. Labour regulations reduce entry into labour intensive sectors but property rights protection increases entry into R\&D intensive sectors, Bertrand and Kramarz (2002). Ciccone and Papaionnaou (2007) find that entry rates are higher when the time for registering new business is lower although this is also influenced by demand and technology factors. However, in these studies the measures of institutional 
heterogeneity are limited to one or a few variables in each country, for example regulatory barriers, and these may be correlated with other country-specific factors, for example macroeconomic policies, exchange rate factors , and tariffs associated with inter-sectoral rates of entry.

Our empirical work focuses on the impact of institutional variation and political discontinuity on regional entry rates in Russia. Russia is a particularly promising country in which to explore this phenomenon. The country has a strong common history and identity. Moreover, the indicators of formal institutional quality are fairly good. According to the 'Doing Business' statistics compiled by the World Bank, Russia registers a high number of procedures to be implemented in order to open a new business (especially for screening), but does not impose high barriers in terms of registration's time and cost. For example advanced Western countries such as Austria and Italy impose significantly higher entry barriers in terms of registration's time and fees. However, the same country scores relatively highly in corruption levels as well as the prevalence of informal economy2. The discrepancy between relatively low formal regulations cost and high corruption index can be explained by the high impact of informal institutions. As argued by Aidis, Estrin, and Mickiewicz (2008), some transition countries, such as Russia, are characterised de facto by a complex system of entry barriers or entry fostering mechanisms.

However, the significant point for our study is that, while Russia is a single country with a unified exchange rate and macro-economic policy regime, regional barriers created by local administrative practices controlled by governors have resulted in fragmentation into regional markets and local market potential at the regional level is an important factor influencing the decision for firms to enter, Berkowitz and DeJong (2005a). Second, as regional governors have a large sway over local legislation

\footnotetext{
2 E.g. Index of Economic Freedom, Heritage Foundation and The Wall Street Journal Index.
} 
as well as informal influence over local state bodies, Popov (2001), OECD (2002), there are potentially significant differences in institutional settings across Russia. Finally, the state and local groups can behave in a predatory manner, Frye and Shleifer (1997), CEFIR (2007), and thus expropriate or diminish generated profits within their region. Therefore, Russian regions provide a useful laboratory for research on potential institutional factors affecting entry rates. The large number of regions and the heterogeneity in their economic and institutional environments, Popov (2001), allows us to disentangle various institutional factors and measure their effects on entry rates. The diversity of economic conditions and the large scope for regional governments to influence local institutions have resulted in significant divergence of regional development paths. This suggests inter-regional differences in both formal and informal institutions might have a significant effect on regional entry rates in Russia, relative to those "natural" rates of entry that one might observe in developed economies. We explore this hypothesis empirically in the remainder of this paper.

\section{MEASURES OF ENTRY AND REGIONAL INSTITUTIONAL QUALITY}

The data used in this paper are drawn from ORBIS database and consist of firm level balance-sheet information spanning from 1996 to 2008. These data cover the bulk of registered firms down to four digit industries in Russia and provide information on shareholders, company's finances, employment count, location, legal status (e.g. limited liability companies, single proprietorship, etc.), year of incorporation3, and company name. The database closely matches information provided by Amadeus (BvD copyright) and this allows us to compare the Russian entry rates we compute with statistics provided by other studies, e.g. Klapper, Laeven, and Rajan (2006) that use the same definitions, methodology and variables. However, unlike Amadeus, ORBIS does not have any firm size restrictions; smaller firms are therefore included in the

\footnotetext{
${ }^{3}$ Information is also provided on the month and day of incorporation, but these are not exploited.
} 
data set and new firm entry tends to be concentrated in this size category.

We follow the literature, Geroski (1995), Klapper, Laeven, and Rajan (2006), in using up to two measures of the entry rate into an industry; annual entry and entry spanning a two year period. We base our measure of entry on the year in which the firm is registered as being incorporated, rather than the more commonly used indicator of the year that the firm first enters the relevant database. This improves the quality of the measure considerably in environments, such as Russia, where reporting standards by firm are not always uniformly applied, so one cannot be sure if a newly reporting firm is in fact an entrant or an enterprise that failed to report consistently in previous years. Thus, Entry 1-year is the number of companies in an industry and region with incorporation year $=\mathrm{T}$ divided by the number of companies with the incorporation year $\leq \mathrm{T}$. Entry 2-year is the number of companies in an industry and region with incorporation year $=\mathrm{T}$ or $(\mathrm{T}-1)$ divided by the number of companies with the incorporation year $\leq \mathrm{T} 4$. Industries are denoted by the subscript ' $\mathrm{i}$ ' on 62 Nace 2 digit dummies (excluding such sectors as agriculture, mining, utility, financial intermediation and public administration); regions are denoted by r, i.e. 88 regions dummies (Chechnya is dropped from the data); time is denoted by $t$, for the years 1996-20085. One of the advantages of ORBIS compared with the Amadeus dataset used by Klapper, Laeven, and Rajan (2006), is that it contains every registered firm, rather than all firms above a certain size. As noted above, this is potentially a great advantage in the analysis of entry, because entrants are typically

\footnotetext{
${ }^{4}$ For brevity all the reported results refer to the 1-year entry rate, but the results hold with the $2^{-}$ year entry measure (available on request).

5 There is a danger that incorporation in the early years of the transition might indicate privatisation rather than new firm entry. However, in fact the bulk of the Russian economy was privatized by 1997 and such instances are rare in our database. We also cannot distinguish between new entry and legal change of name, which may have occurred in later years. The legal change of name, however, is often a result of change of ownership and thus represents a new way of recombining a firm's resources and introduction of a new strategy. While this does not constitute a de novo entry as such, it still often signifies entry of a new owner or a new approach to the market. Our data however may overstate entry rates because of this phenomenon.
} 
much smaller than incumbents, Geroski (1995). However, it brings a potential drawback because our measure of entry is based on the date of incorporation since a significant number of small firms entering the regional market may be unregistered. We noted above that Russia scores poorly with respect to the scale of the informal economy. To address the resulting bias, we also estimated our econometric models on a four dimensional database (region, industry, year and firm-size ${ }^{6}$ ), which increases the size of the sample and captures the differential effect of institutions on entry-size categories. In this experiment, the dependent variable is defined in the following way: Entry 1-year is the number of companies with incorporation year $=\mathrm{T}$ of a specific size category divided by the number of companies with the incorporation year $\leq \mathrm{T}$ of the same size category. We adopt a standard size taxonomy by employees, namely s $1<50$, $\mathrm{s} 2=[51-250], \mathrm{s} 3>250^{7}$.

New firm entry rates in Russia as a whole do not appear to be particularly low by international standards ${ }^{8}$. Thus we find that rate entry is registered in an interval between $11.9 \%$ and $2.4 \%$ throughout the $1996-2008$ span compared with $7.09 \%$ in Europe and $6.65 \%$ in the USA using the same NACE industries in 1998/9, Dun and Bradstreet (2000). However, Russian rates are quite low for emerging markets as a whole, Estrin and Campos (2007). Moreover, the entry rates calculated using ORBIS are high compared with figures when using Amadeus, Aidis and Adachi (2007). This is partly because entry rates are higher for small firms, most of which are excluded from other datasets. In fact, annual average annual entry rates for large firms,

6 The theoretical overall number of data of the database is therefore $13 \times 62 \times 88=70928$. However there are missing industries in some regions. Our dataset contains around 50000 observations and over 100000 when we account for the firm size effect.

7 The overall sample exploits all the firms declaring the date of incorporation (see also footnote 14). The size level database is build by splitting the overall firm sample in three parts according to their size category. Entry rates are computed within separate categories. Finally the three parts are pooled back together in a single size-level database. Some firms do report date of incorporation but not size and therefore are part of the all sample database. Only firms reporting date of incorporation and size are included in the size level data.

${ }^{8}$ See tables A1.1 and A1.2 and graphs A1.1 and A1.2 from appendix 1. 
employing more than 250 workers, are around $4.3 \%$ and tending to decline over time (6.7\% in 1996 and $0.4 \%$ in 2008 ), while those for the smallest firms are around $11.3 \%$. However, the issue is more complex than this because there is also more year to year variation in the small firm category. Moreover, high gross entry rates do not necessarily imply high net entry rates if survival rates are low, Brown and Earle (2006) and Rutkowski and Scarpetta (2005)9.

The fragmented nature of political structures creates significant barriers to the creation of a unified market across Russia. As a result, Russian regions differ significantly, for example in their wealth, income levels, risk of social tensions and administrative barriers to start-ups, and therefore in the institutional environment with respect to entry. Thus, while several regions have been shown to have a legislative climate favourable to investors, such as Nizny Novgorod, Yaroslavl and Moscow, others, such as Kursk and Magadan, lag behind. The OECD (2002) report on trading policy in Russian regions illustrates the diversity of institutional setting. For example, Cheliabinsk oblast introduced additional procedures and higher fees than those stipulated by federal law for such activities as employment services, international tourism, passenger transportation as well as production and marketing of alcohol. Primorskiy krai decreed higher fees for licensing pharmaceuticals, while Nizhny Novgorod extended licensing requirements for engineering systems, building and road maintenance. The republics of Udmurtia and Mordovia introduced regional certification of companies, restricting entry. To explore the link between entry and institutional environment, we compile a dataset containing measures of institutional environment at the regional level, drawing on two further data sources. These are a newly constructed database on governor turnover in the Russian regions between

9 The corresponding values for the 2 years entry rate, show similar patterns between Europe and USA, whilst Russia entry rates are higher. This may be due to a post 1998 shake-out effect: the number of firms entering the market in the 1999 and 2000 year might have been abnormally high due to the rebound from the end of the crisis. 
1995 and 200910 and the democratisation scores compiled by McFaul, Petrov, and Ryabov (2004).

We are able to exploit regional variations in Russia because regional authorities have discretion in such areas of joint responsibility with the central government as ownership, land use and management, mineral resources, as well as some authority over taxes11. Moreover, regional authorities have formal power and responsibility over local financial aid and subsidies, government procurement, investment and trade promotion, control over natural resources, environment protection and licensing. Finally, local regional authorities have considerable discretionary powers, based on informal practices and the use of administrative resources. Consequently, they can exercise informal control over local market institutions which affect the ease of creating and operating a firm. For example, they control factory inspections. Thus, an average small company in Kurgan oblast in 2001 was inspected 10 times compared to 2.5 times in Samara oblast over the same time period, CEFIR (2007).

Local governors have great leverage in establishing the local "'rules of the game" for businesses. Although the ability of regional authorities to form local policies entirely independently of the central government waned after 2000, local informal practices and networks have preserved the diversity of local institutions that affect formation of new firms. A wide array of institutions can affect business environment and therefore entry, ranging from the quality of local judicial system, law enforcing organs, licensing practices, local inspectorates, the financial system and local bureaucracy,

${ }^{10}$ We will only exploit the 1996-2008 interval for consistency with entry rates.

11 In 2002 a new order of profit taxation was established in the Russian Federation by implementing a decrease of corporate profit tax rate from 35 to $24 \%$. Tax revenues decreased from 513,8 billion Roubles in 2001 to 463,3 billion Roubles in 2002. However, in 2004 profit tax revenues reached 867,6 billion Roubles, and their average annual increase in 2002-2004 was $36,8 \%$. Considering the revenues increase and that effective profit tax rate decreased from $25,1 \%$ in 2000 to $17,8 \%$ in 2003 it may be deduced that the tax revenues increase was influenced by the very rapid expansion of tax base, Krivka (2006). However, this was a national level reform and cannot be exploited in our analysis of inter-regional variation. 
Lambert-Mogiliansky, Sonin, and Zhuravskaya (2007), CEFIR (2007), Brown, Earle, and Gehlbach (2009), Orrtung (2004). These, however, tend to be highly correlated, and difficult to operationalise. To circumvent this problem we measure the institutional environment by focusing on one of the crucial considerations for a new entrant - predictability of the political continuity and, as a consequence, of the business environment.

We capture the periodic uncertainty that stems from the expiry of the current governor's term in the office by measuring political discontinuity. This variable is of a particular salience to Russia as Russian governors tend to run their regions as "personal fiefdoms", Treisman (2002), Ross (2003), and exert great influence over regional political and economic process. As emphasized by Orttung (2004: 58) "the governors' enormous influence on regional budgets, licenses, electricity prices, and the overall conditions in which business operates means that any business seeking to function in the regions must take them into account". Despite recent attempts at recentralisation, governors retained enormous influence over regional political and economic life, Konitzer and Wegren (2006).

Furthermore, because both political and economic decisions are highly personalised, a change of governor and his team is likely to lead to significant changes in how business is done in the region. This will involve a change in ties to business groups, envisioned economic policies, investment programmes and, importantly, new informal rules of the game. Moreover, due to the weakness of formal institutions there is little continuity of policies. Since so many decisions and practices are based on personal ties and loyalties, personnel changes in the higher echelons of the local administration inevitably spell uncertainty in regard to future practices and policies. Therefore even the possibility of a change in governor is likely to create uncertainty over change in 
local business practices.

With these sets of indicators in mind we constructed a novel dataset measuring political discontinuity at the governor level. These indicators reflect the systemic uncertainty which affects regional businesses every four years as the gubernatorial term in the office expires and the incumbent faces the risk of being replaced by another candidate. It is assumed that fewer changes in governor, as well as a lower level of political conflict, contribute to a more stable investment environment, i.e. higher political continuity. With the same governor and political elite in office over a longer time period, entrepreneurs can build links with more stable and durable links with local politicians and use these as a basis for longer-term investment decisions. A new governor with a different political background might introduce his or her own group of associates, disrupting existing links and creating potential investment insecurity. To capture the level of uncertainty associated with potential change of governor, we constructed a governor turnover dataset by documenting instances when the incumbent governor's term in the office expired (whether he or she stood for reelection or re-appointment), instances of governor change (again, whether through elections or re-appointment) and the quality of these changes. The latter indicator reflects the likelihood of policy continuity after the possible change of governor and consequently, the degree of uncertainty faced by local businesses. The degree of uncertainty (called in the regressions "political discontinuity") stemming from potential governor's change was measured on a three point scale- i.e. [0,3] - for each year during the period 1996-2009. This was done to capture the gradation of uncertainty caused by different scenarios of potential power change. Thus, zero represents status quo, and was assigned to years when no election or governor appointment took place. Years when the current governor stood for re-election or reappointment, but where the incumbent remained in power were assigned a value of 1 . 
Instances, when the incumbent was replaced by a candidate from the same political elite were assigned a value of 2 . Cases when the new governor came from the opposition were given the value of 3 .

By distinguishing between different scenarios in governor change we are able to capture the nuanced nature of uncertainty associated with potential political change at the governor level. In effect, the cumulative12 indicator measures the increasing degree of uncertainty faced by a prospective entrant in cases of:

- no foreseeable change in governor and therefore stable economic and political policies;

- a possible change in governor in which, the incumbent remained in office and therefore continuity of present policies;

- a new governor coming to power, who, being part of the same political group, is likely to provide some elements of continuity of previous policies but also possibly some change;

- election of a new governor from an opposition party who is likely to discontinue current policies and practices.

This categorisation in conjunction with other indicators allows us to distinguish between change per se and quality of change. By introducing this distinction we seek to separately measure the impact of institutional improvement (or deterioration) as well as to gauge the impact of change itself.

Predictability can also stem from transparency of decisions taken by the governing elite. As argued by Mau and Yanovsky (2002), firms want to operate with an understandable, transparent and predictable system of decision-making, rather than

12 The cumulative indicator is constructed by adding $0,1,2$ or 3 for each year in which there is a change in the political uncertainty environment. 
being dependent on the whim of an individual. Democratic practices and political openness are thought to generate transparency and preclude rulers from acting unilaterally. Acemoglu and Johnson (2005) posit that it is democratic institutions which give rulers the incentives to establish economic institutions conductive to growth. First, without the checks and balances that democracy provides, rulers are likely to establish economic institutions beneficial to a small group and detrimental to the remainder of society. Second, democracy vests power in a broad group of people, thus giving them an incentive to uphold secure property rights as they themselves benefit from this. Finally good economic institutions, identified as secure property rights, are more likely to develop when rulers can extract only limited rents from the society (ibid). This leads us to measure the transparency and openness of regional political processes in Russia as an alternative indicator of institutional quality that may affect new firm entry.

This suggests that in Russia, where there is considerable regional variation, it is also important to consider the impact of democratic practices on entry rates in Russian regions. As suggested by theoretical literature, these can provide some institutional stability to offset uncertainty generated by political discontinuity. We measure institutional quality via the extent of media freedom, level of democracy and the extent of openness of regional political life. We aim to capture predictability of regional political and economic processes that stems from access to information and involvement in political life of the region. We gauge the equality of opportunities for all economic players by measuring the quality of economic openness in the region. This measure includes the extent of economic liberalisation and the degree of corruption.

The set of indicators to measure the quality of democracy and therefore the predictability of regional institutions were sourced from an important new dataset 
collected by McFaul, Petrov, and Ryabov (2004). The dataset includes 10 subindicators, which together provide an assessment of political and economic openness in each region. In our estimations, we use both the summary variable for democratisation (composed out of all 10 sub-indicators), and the 10 sub-indicators separately, but for brevity we report the aggregate indicator only, the results being broadly consistent13. The sub-indicators give respectively an account of political factors (political openness, elections, pluralism, regional political structure), economic factors (economic liberalization, corruption), and civil-society and social factors (media, civil society, elites, local self-government). Together, they capture the openness of regional political and economic processes and indicate how easy it is for a new entrant to gauge future profits from the venture and estimate the likelihood of losing the investment.

\section{ESTIMATION STRATEGY}

In order to test the relationship between entry and institutions, we run a Tobit estimation model for the censored [0.1] entry variable computed from the year of incorporation declared by the firm 14 . We exploit the Klapper, Laeven, and Rajan (2006) methodology drawn from the difference in difference approach used by Rajan Zingales (1998). The specification includes regional fixed effects - D r -, industry fixed effects (62 Nace 2-digit industries, excluding agriculture, mining, utility, financial intermediation and public administration that show a structurally lower entry rate) D i -, time fixed effects - D t - (13 years). We also include the interaction term Entry EU [1998-2003] * INSTITUTION Region-Year(-1) or Entry EU [1998-2003] * INSTITUTION Region-Year(-2). This specification is equivalent to testing whether

\footnotetext{
13 Tables available upon request.

${ }^{14}$ The "Date of Incorporation" is reported by $85 \%$ of firms. We dropped from the database the $15 \%$ non-declaring firms.
} 
institutions differentially affect entry rates given the "natural entry rate"15, the latter reflecting the long run barriers to entry for the given industry in a developed market economy.

The institutional variables are loaded, either as the governors' turnovers indicators or the Petrov data and natural entry rates are sourced from EU 1998-2003 data16. Aghion, Blundell, Griffith, Howitt, and Prantl (2004) analyse entry determinants using both structural variables and exogenous variation via instrumental variable estimation in order to tackle potential reverse causality, namely that entry might improve institutions, could in principle occur in our specification if a sector-region specific entry rate affects the institutional environment of the region. However, we think this to be unlikely in our data because the dependent variable varies across regions, time and industry, whereas the potentially endogenous regressor is at the regional-time level only. The regressions also contain the full set of regional, sectoral and time dummies ${ }^{17}$.

The following models are estimated, where the subscript "i" stands for industry " $r$ " stands for region, "t" stands for time and "s" stands for the three size categories $\mathrm{s} 1<50, \mathrm{~s} 2=[51-250], \mathrm{s} 3>25018:$

${ }^{15}$ For example, consider two sectors only, with natural entry rates of 0 and 1 , respectively. The interaction term Entry EU [1998-2003] * INSTITUTION Region-Year(-1) will capture exactly the impact of institutions on the $100 \%$ entry sector with respect to the no entry one.

16 We also use USA data for 1998-1999 as robustness check. They results are broadly, but not fully, consistent and we attribute this to three reasons: 1) the natural entry rates concept is better assessed as a long longer average (in EU is 1998-2003) 2) we lose many sectors when using the USA data, 3) We do not have size specific entry rates for USA.

17 The inclusion of time dummies is alternative to time trend and it is particularly important for non stationary time series. The entry rates have been showing a decreasing pattern between 1996 and 2008 and this will be captured by time dummies. However, the panel time series do not show the existence of a unit root, which would possibly bias the estimates of the coefficients. See Appendix 3 for a battery of tests on unit root in panels for our dataset.

${ }_{18}$ For robustness check the same regressions are also run with the institutional variables loaded as 2 years lag, i.e. INSTITUTION Region-Year-2). 1 years and 2 years results are both reported in tables. 
Entry r,i,t $=\sigma$ Entry EU [1998-2003] * INST R-Yr(-1) $+\sum_{\mathrm{r}} B_{\mathrm{r}} \mathrm{D}_{\mathrm{r}}+\sum_{\mathrm{i}} \beta_{\mathrm{i}} \mathrm{D}_{\mathrm{i}}+\sum_{\mathrm{t}} B_{\mathrm{t}} \mathrm{D}_{\mathrm{t}}+\varepsilon_{\mathrm{r}, \mathrm{i}, \mathrm{t}}$

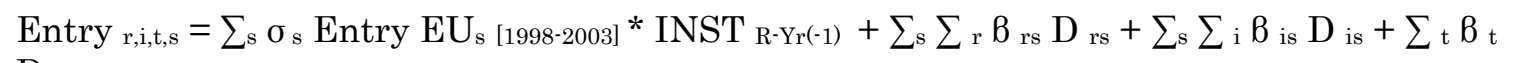
$\mathrm{D}_{\mathrm{t}}+\varepsilon_{\mathrm{r}, \mathrm{i}, \mathrm{t}, \mathrm{s}}$

In equation 2 the interaction term between institutions and the natural entry rate, as well as regional and sectoral dummies, are included for all the three size categories $\sum_{\mathrm{s}}$ - (for a comparison see Aghion, Fally, and Scarpetta (2007)), time dummies are unmodified.

\section{RESULTS}

In reporting the estimation results for equations (1) and (2), we are particularly interested in the sign of the coefficients $\sigma$ and $\sigma(\mathrm{s} 1), \sigma(\mathrm{s} 2), \sigma(\mathrm{s} 3)$ stemming from the coefficient of the interacted terms by size $\left(\sum_{\mathrm{s}} \sigma_{\mathrm{s}}\right)$. The dependent variable is the 1-year entry rate at the level of the sector, region and year in equation (1) and the 1-year entry rate at the level of the sector, region, and year and size category in equation (2) 19. Thus, the former exploits the three dimensional data base (region, industry and time), whereas the latter exploits the four dimensional one (region, industry, time and size). These results are discussed in section 5.1. The results using the Petrov democratisation measure are reported in section 5.2.

Our empirical investigation poses the question whether industries characterised by higher "natural entry rates" will suffer relatively more in terms of entry if based in regions with an adverse business climate, measured by the uncertainty about governors' continued incumbency in office and political inclination (pro-incumbent

\footnotetext{
${ }^{19} \mathrm{We}$ also run all regressions with the 2 year entry rate as dependent variable and the results are fully consistent with the 1 year entry results (available on request by the authors).
} 
versus opposition). As explained in section 3 (with more details in appendix 2), we constructed the governor's political discontinuity indicator on a $[0,3]$ scale. To facilitate the interpretation of the coefficients of the Tobit regression model, we adopt two transformations: we re-scaled the institutional variables (democratisation as well as the governors turnovers) so that they strictly vary in the $[0,1]$ interval; we report the Tobit marginal effects on truncated expected value at 0 (lower bound) and 1 (upper bound). These transformations allow us to interpret the magnitude of the $\sigma$ and $\sigma_{\mathrm{s}}$ coefficients as the percentage decrease of the natural entry rate for an average region passing from the best to the most uncertain political/democratisation environment. We now proceed by commenting separately on each group of institutional variables. 


\subsection{Governors' Turnovers and the entry rates}

TABLE 1.-INSTITUTIONAL DETERMINANTS OF ENTRY

\begin{tabular}{|c|c|c|c|c|c|c|c|c|}
\hline & (i) & (ii) & (iii) & (iv) & (v) & (vi) & (vii) & (viii) \\
\hline & $\mathrm{Y}(-1)$ & Election & \multicolumn{2}{|c|}{ Governor's Change } & \multicolumn{2}{|c|}{ Elite's Change } & \multicolumn{2}{|c|}{ Pol. Discontinuity } \\
\hline Entry EU [1998-2003] * Elect Year(-1) & $\begin{array}{l}0.010 \\
(0.095)\end{array}$ & & & & & & & \\
\hline Entry EU [1998-2003] * Elect Year(-22)) & & $\begin{array}{l}-0.071 \\
(0.086)\end{array}$ & & & & & & \\
\hline $\begin{array}{l}\text { Entry EU [1998-2003] * Gov Change } \\
\text { Year(-1) }\end{array}$ & & & $\begin{array}{l}-0.493^{*} \\
(0.121)\end{array}$ & & & & & \\
\hline $\begin{array}{l}\text { Entry EU [1998-2003] * Gov Change } \\
\text { Year(-2) }\end{array}$ & & & & $\begin{array}{l}-0.670^{* * *} \\
(0.174)\end{array}$ & & & & \\
\hline $\begin{array}{l}\text { Entry EU }[1998-2003] \text { * Elite Change } \\
\text { Year(-1) }\end{array}$ & & & & & $\begin{array}{l}-0.046 \\
(0.092)\end{array}$ & & & \\
\hline $\begin{array}{l}\text { Entry EU [1998-2003] * Elite Change } \\
\text { Year(-2) }\end{array}$ & & & & & & $\begin{array}{l}-0.122 \\
(0.161)\end{array}$ & & \\
\hline $\begin{array}{l}\text { Entry EU [1998-2003] * } \\
\text { Pol. Discontinuity Year(-1) }\end{array}$ & & & & & & & $\begin{array}{l}-0.168^{*} \\
(0.086)\end{array}$ & \\
\hline $\begin{array}{l}\text { Entry EU [1998-2003] * } \\
\text { Pol. Discontinuity Year(-2) }\end{array}$ & & & & & & & & $\begin{array}{l}-0.303^{* * *} \\
(0.073)\end{array}$ \\
\hline $\begin{array}{l}\text { Di: } 2 \text { Digit NACE Sector } \\
\text { Dummies }\end{array}$ & $\mathrm{Y}^{* * *}$ & $\mathrm{Y}^{* * *}$ & $\mathrm{Y}^{* * *}$ & $\mathrm{Y}^{* * *}$ & $\mathrm{Y}^{* * *}$ & $\mathrm{Y}^{* * *}$ & $\mathrm{Y}^{* * *}$ & $\mathrm{Y}^{* * *}$ \\
\hline Dr: Regions Dummies & $\mathrm{Y}^{* * *}$ & $\mathrm{Y}^{* * * *}$ & $\mathrm{Y}^{* * *}$ & $\mathrm{Y}^{* * *}$ & $\mathrm{Y}^{* * *}$ & $\mathrm{Y}^{* * *}$ & $\mathrm{Y}^{* * *}$ & $\mathrm{Y}^{* * * *}$ \\
\hline Dt: Year Dummies & $\mathrm{Y}^{* * *}$ & $\mathrm{Y}^{* * * *}$ & $\mathrm{Y}^{* * *}$ & $\mathrm{Y}^{* * *}$ & $\mathrm{Y}^{* * * *}$ & $\mathrm{Y}^{* * *}$ & $\mathrm{Y}^{* * *}$ & $\mathrm{Y}^{* * * *}$ \\
\hline Observations & 51600 & 47300 & 51600 & 47300 & 51600 & 47300 & 51600 & 47300 \\
\hline
\end{tabular}

Table 1 reports four institutional variables and two specifications for each of them, i.e.

1 year and 2 years lags. Columns (i) and (ii) refer to the "Election" variable (0 no election, 1 election year). We do not register any effect. This is presumably because the timing of elections in Russia are perfectly predictable and therefore one would not expect them to have an impact on the decision to enter in a market, unless one also expects some political change to accompany the election (see regression by size categories). Columns (iii) and (iv) refer to "Governor's Change" variable (0 no change, 1 change of governor). If we interpret a change of governor as an indicator of increased political instability, we can register a decreased likelihood of entry of the order of $49 \%(67 \%)$ of the natural entry rate one year (two years) after the change of governor. This is not negligible: for example, an industry with a natural entry rate of 
$5 \%$ (e.g. sale motor vehicles), which is located in a region passing from no political change to the replacement of the governor, would experience a reduction of entry of the order of the $49 \%$ of its natural entry rate, i.e. 2.5 percentage points loss after one year. The effect would be even bigger two years after the change $(-3.35 \%)$. Columns (v), (vi) refer to the variable measuring a change of governor as well as a change of the political elite ( 0 no change in political elite, 1 otherwise). The election of a "new" governor belonging to an "opposition" ${ }^{20}$ political circle of the incumbent has a negative impact ( 1 and 2 years later) on entry, but the coefficients are not significant.

Finally, columns (vii) and (viii) refer to our preferred summary indicator of political discontinuity variable (normalised on the $[0,1]$ interval) and we find that if there is less predictability in the political arena, i.e. there is higher discontinuity with respect to the previous gubernatorial situation, there is an important negative effect on entry after two years ${ }^{21}$.

${ }^{20}$ Opposition with respect to the incumbent, not with respect to any left/right political spectrum. 21 The coefficient is $-0.303^{* * *}$ : in case of a region passing from the status quo to the higher discontinuity (replacement of the incumbent governor with a new governor from the opposition) there will be a decrease of $30 \%$ in the sector specific natural entry rate. We also run a "horse race" type of regression by including all the three indicators (election, governor's change, elite's change), instead of the summary indicator on political discontinuity, and the results remain consistent. 
TABLE 2.-INSTITUTIONAL DETERMINANTS OF ENTRY: THE SizE EFFECT

\begin{tabular}{|c|c|c|c|c|c|c|c|c|}
\hline & (i) & (ii) & (iii) & (iv) & (v) & (vi) & (vii) & (viii) \\
\hline & \multicolumn{2}{|c|}{ Election } & \multicolumn{2}{|c|}{ Governor's Change } & \multicolumn{2}{|c|}{ Elite's Change } & \multicolumn{2}{|c|}{ Political Discontinuity } \\
\hline & $\mathrm{Y}(-1)$ & $\mathrm{Y}(-2)$ & $\mathrm{Y}(-1)$ & $\mathrm{Y}(-2)$ & $\mathrm{Y}(-1)$ & $\mathrm{Y}(-2)$ & $\mathrm{Y}(-1)$ & $\mathrm{Y}(-2)$ \\
\hline$\{$ Small\} Entry EU [1998-2003] * & $0.202^{* * *}$ & & & & & & & \\
\hline Llect Year(-1) & $(0.051)$ & & & & & & & \\
\hline $\begin{array}{l}\text { \{Medium\} Entry EU [1998-2003] } \\
\text { * Elect Year(-1) }\end{array}$ & $-1.598^{* * *}$ & & & & & & & \\
\hline $\begin{array}{l}\{\text { Large } \text { Entry EU [1998-2003] * } \\
\text { Elect Year(-1) }\end{array}$ & $\begin{array}{l}(0.161) \\
-3.413^{* * *}\end{array}$ & & & & & & & \\
\hline $\begin{array}{l}\left\{\text { Small\} Entry EU }{ }_{[1998-2003]} \text { * }\right. \\
\text { Elect Year(-2) }\end{array}$ & $(0.194)$ & $0.222^{* * *}$ & & & & & & \\
\hline $\begin{array}{l}\text { \{Medium\} Entry EU [1998-2003] } \\
\text { * Elect Year(-2) }\end{array}$ & & $\begin{array}{l}(0.043) \\
-1.537^{* * *}\end{array}$ & & & & & & \\
\hline $\begin{array}{l}\{\text { Large }\} \text { Entry EU [1998-2003] * } \\
\text { Elect Year(-2) }\end{array}$ & & $\begin{array}{l}(0.194) \\
-3.336^{* * *}\end{array}$ & & & & & & \\
\hline $\begin{array}{l}\{\text { Small\} Entry EU [1998-2003] * } \\
\text { Gov Year(-1) }\end{array}$ & & $(0.327)$ & 0.082 & & & & & \\
\hline $\begin{array}{l}\text { \{Medium\} Entry EU [1998-2003] } \\
\text { * Gov Year(-1) }\end{array}$ & & & $\begin{array}{l}(0.053) \\
-1.657^{* * *} \\
(0.353)\end{array}$ & & & & & \\
\hline $\begin{array}{l}\{\text { Large } \text { Entry EU [1998-2003] * } \\
\text { Gov Year(-1) }\end{array}$ & & & $-3.215^{* * *}$ & & & & & \\
\hline $\begin{array}{l}\{\text { Small\} Entry EU [1998-2003] * } \\
\text { Gov Year(-2) }\end{array}$ & & & $(0.355)$ & 0.074 & & & & \\
\hline $\begin{array}{l}\text { \{Medium\} Entry EU [1998-2003] } \\
\text { * Gov Year(-2) }\end{array}$ & & & & $\begin{array}{l}(0.071) \\
-1.490^{* * *}\end{array}$ & & & & \\
\hline $\begin{array}{l}\text { \{Large\} Entry EU [1998-2003] * } \\
\text { Gov Year(-2) }\end{array}$ & & & & $\begin{array}{l}(0.316) \\
-3.067^{* * *} \\
(0.516)\end{array}$ & & & & \\
\hline $\begin{array}{l}\{\text { Small\} Entry EU [1998-2003] * } \\
\text { Same Elite Year(-1) }\end{array}$ & & & & & $\begin{array}{l}0.116 \\
(0.075)\end{array}$ & & & \\
\hline $\begin{array}{l}\text { \{Medium\} Entry EU [1998-2003] } \\
\text { * Same Elite Year(-1) }\end{array}$ & & & & & $\begin{array}{l}-2.179^{* * *} \\
(0.280)\end{array}$ & & & \\
\hline $\begin{array}{l}\{\text { Large\} Entry EU [1998-2003] * } \\
\text { Same Elite Year(-1) }\end{array}$ & & & & & $\begin{array}{l}-3.648^{* * *} \\
(0.497)\end{array}$ & & & \\
\hline $\begin{array}{l}\{\text { Small\} Entry EU [1998-2003] * } \\
\text { Elite Change Year(-2) }\end{array}$ & & & & & & $\begin{array}{l}0.066 \\
(0.112)\end{array}$ & & \\
\hline $\begin{array}{l}\text { \{Medium\} Entry EU [1998-2003] } \\
\text { * Elite Change Year(-2) }\end{array}$ & & & & & & $\begin{array}{l}-1.942^{* * *} \\
(0.164)\end{array}$ & & \\
\hline $\begin{array}{l}\{\text { Large }\} \text { Entry EU [1998-2003] * } \\
\text { Elite Change Year(-2) }\end{array}$ & & & & & & $\begin{array}{l}-3.394^{* * *} \\
(0.595)\end{array}$ & & \\
\hline $\begin{array}{l}\{\text { Small\} Entry EU [1998-2003] * } \\
\text { Pol Discontinuity Year(-1) }\end{array}$ & & & & & & & 0.116 & \\
\hline $\begin{array}{l}\text { \{Medium\} Entry EU [1998-2003] } \\
\text { * Pol Discontinuity Year(-1) }\end{array}$ & & & & & & & $\begin{array}{l}(0.081) \\
-1.682^{* * *} \\
(0.148)\end{array}$ & \\
\hline $\begin{array}{l}\{\text { Large\} Entry EU [1998-2003] * } \\
\text { Pol Discontinuity Year(-1) }\end{array}$ & & & & & & & $\begin{array}{l}-3.387^{* * *} \\
(0.326)\end{array}$ & \\
\hline $\begin{array}{l}\{\text { Small\} Entry EU [1998-2003] * } \\
\text { Pol Discontinuity Year(-2) }\end{array}$ & & & & & & & & 0.114 \\
\hline $\begin{array}{l}\text { \{Medium\} Entry EU [1998-2003] } \\
{ }^{*} \text { Pol Discontinuity Year(-2) }\end{array}$ & & & & & & & & $\begin{array}{l}(0.075) \\
-1.557^{* * *} \\
(0.089)\end{array}$ \\
\hline $\begin{array}{l}\text { \{Large\} Entry EU [1998-2003] * } \\
\text { Pol Discontinuity Year(-2) }\end{array}$ & & & & & & & & \\
\hline $\begin{array}{l}\text { Dr*[size }]: \text { Regions * Size } \\
\text { Dummies }\end{array}$ & $\mathrm{Y}^{* * *}$ & $\mathrm{Y}^{* * *}$ & $\mathrm{Y}^{* * *}$ & $\mathrm{Y}^{* * *}$ & $\mathrm{Y}^{* * *}$ & $\mathrm{Y}^{* * *}$ & $\mathrm{Y}^{* * *}$ & $\begin{array}{l}(0.221) \\
\mathrm{Y}^{* * *}\end{array}$ \\
\hline $\begin{array}{l}\mathrm{Di}^{*}[\text { size }]: 2 \text { Digit NACE } \\
\text { Sector* Size Dummies }\end{array}$ & $\mathrm{Y}^{* * *}$ & $\mathrm{Y}^{* * *}$ & $\mathrm{Y}^{* * * *}$ & $\mathrm{Y}^{* * *}$ & $\mathrm{Y}^{* * *}$ & $\mathrm{Y}^{* * *}$ & $\mathrm{Y}^{* * *}$ & $\mathrm{Y}^{* * *}$ \\
\hline Dt: Year Dummies & $\mathrm{Y}^{* * *}$ & $\mathrm{Y}^{* * *}$ & $\mathrm{Y}^{* * * *}$ & $\mathrm{Y}^{* * *}$ & $\mathrm{Y}^{* * *}$ & $\mathrm{Y}^{* * *}$ & $\mathrm{Y}^{* * *}$ & $\mathrm{Y}^{* * *}$ \\
\hline Observations & 109404 & 100287 & 109404 & 100287 & 109404 & 100287 & 109404 & 100287 \\
\hline
\end{tabular}

Tobit Regression, coefficients and bootstrapped standard errors in parentheses: ${ }^{* * *} \mathrm{p}<0.01,{ }^{* *} \mathrm{p}<0.05,{ }^{*} \mathrm{p}<0.1$. Source: Authors' computations on ORBIS Database (BvD August 2010 release) and 'Governors' cumulative Turnover data' (see text and appendix 2 for details). Notes: dependent variable defined as 1-year entry rate in the region, sector, size and year. 'Natural entry' rate defined as 1-year entry in European Union as 1998-2003 average within the relevant 2-digit entry rate in the region, sector, size and year. 'Natural entry' rate defined as 1 -year entry in European Union as $1998-2003$ average within the relevant 2 -digit
NACE rev. 1.1 sector. Coefficients reported as marginal effect on truncated expected value at 0 (lower bound) and 1 (upper bound). All regressions include [88 Macro Regions]*[size], [62 Sector]*[size] and 13 Time dummies. the null hypothesis of joint zero coefficients for the $\mathrm{Dr}^{*}[\mathrm{size}] ; \mathrm{Di}^{*}[\mathrm{size}], \mathrm{Dt}^{2}$, respectively, is always rejected at $1 \%$ level $\left(\mathrm{Y}^{* * *}\right)$. 
These results bundle together all type of firms, small, medium and large. In Table 2, we dissect the differential impact of political predictability on these three categories of firms and we discover much richer dynamics. In fact, we find that regardless of lag, the impact of the political instability is much more marked for large firms, and to some extent medium sized ones when there are elections, change of governors and change of elite, whereas the effects are in-significant -or positive and significant in case of elections- for small firms. This result is important because small firms represent a higher proportion of the enterprise sample (44\%), so the average notsignificant result showed in Table 1 is therefore affected by this sample composition. When this is taken in to account the detrimental effect on medium and especially big firms is even more marked. Columns (vii) and (viii) signal a strong negative impact of political discontinuity on medium and especially big firms, whereas small firm show to be un-affected (not significant coefficients) by our preferred summary indicator.

We therefore find that discontinuity of the political and business environment in a region exerts a significant negative effect on the deviation of entry rates by sector from their "natural" levels. While the election process per se does not affect the deviation, a replacement or electoral defeat of an incumbent governor has a marked effect on the entry process; halving the natural rate within one year and decreasing it even more in a subsequent year. This result is robust to alternative specifications that take account of the size distribution of firms. Interestingly, it would seem that political discontinuity impacts most on larger firms. The highly personalized and informal character of regional government is highlighted by the fact that this negative effect of gubernatorial change is independent of the political direction of that change. We do not in our study make any analysis of the attitudes or the policy stances of either gubernatorial incumbents or their opponents. Thus, a change in governor in our 
dataset may imply the replacement of a "red" governor by a pro-market reformer, or the converse. It is the fact that the governor has changed, and presumably that therefore the political, economic policy and business environment will alter, that leads to the reduction in entry rates rather than the political character of that change.

In the next section, we go on to consider whether the deviation of entry rates from their natural sectoral levels is also influenced by the nature of the regional political environment. One might expect that more vigorous political support for market structures, property rights and competition would stimulate entry. Hence one might infer that gubernatorial changes which enhance entry might be associated with political shifts in a pro-market direction. However, one cannot necessarily infer this from our data. This is because the two data sources are unrelated. The political change data was collected by ourselves (see appendix 2 for details) and can be regarded as exogenous from the entry process; the timing of elections and their results seem highly unlikely to be caused by entry rates up to two years hence. The second data source, from McFaul, Petrov, and Ryabov (2004), is much richer in that it seeks to identify the quality of local democracy, which as noted above, Acemoglu and Johnson (2005), among others regard as a key indicator of the quality of market supporting institutions more generally. It may help us to infer the relationship between gubernatorial change and the policy environment. However, it is less obvious that reverse causality can be ruled out with the use of this dataset; high entry rates may help to engender a more democratic political environment to some extent, though perhaps this is less likely when lags are taken into account. Moreover, we do not analyse entry rates, but the deviation from their natural level by sector. Nonetheless, the regressions which follow potentially enrich our analysis of the institutional environment and entry across regions in Russia, but must be regarded as less reliable than the equations reported above. 
TABLE 3.-DEMOCRATISATION DETERMINANTS OF ENTRY

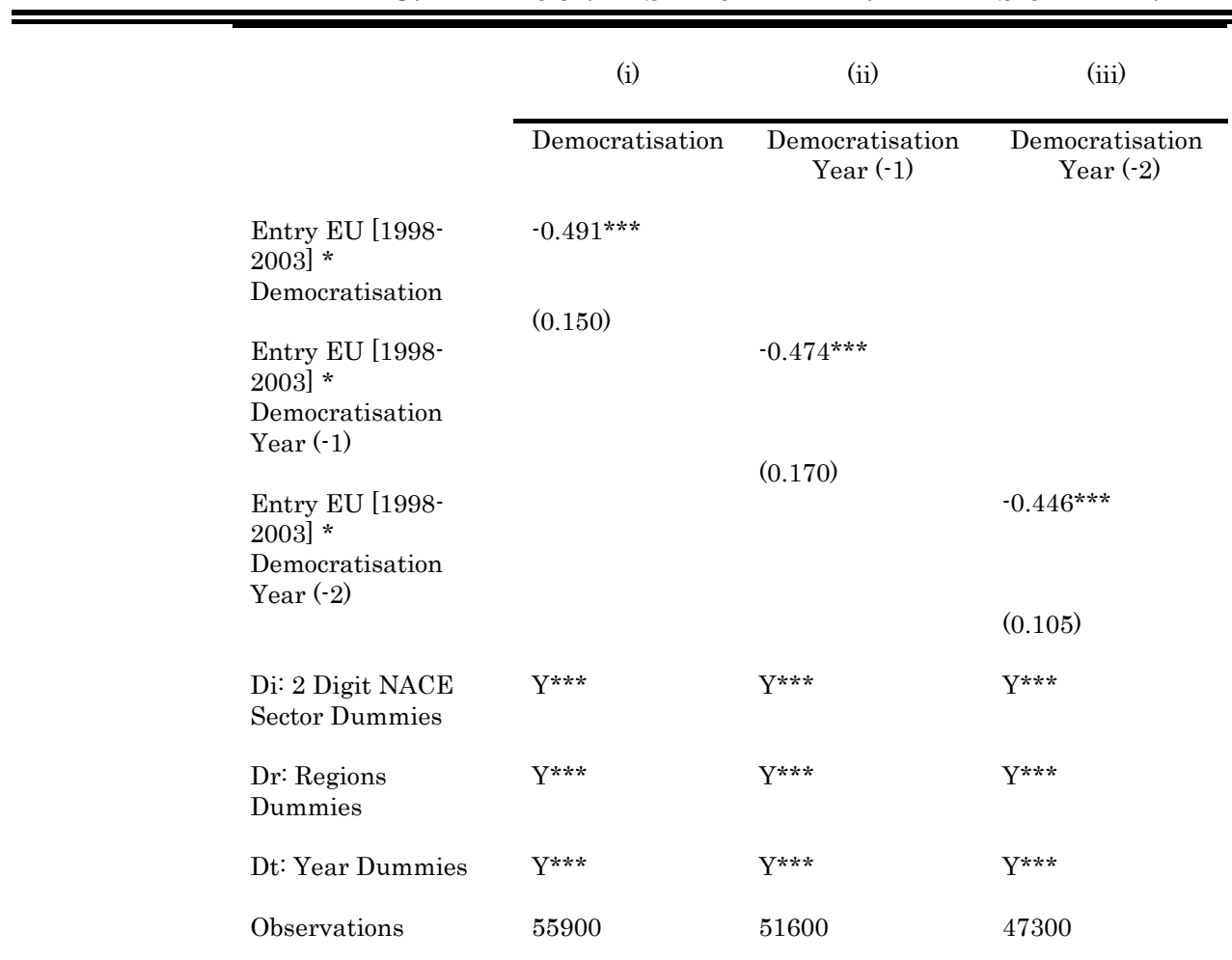

Tobit Regression, coefficients and bootstrapped standard errors in parentheses: *** $\mathrm{p}<0.01,{ }^{* *} \mathrm{p}<0.05,{ }^{*} \mathrm{p}<0.1$. Source: Authors' computations on ORBIS Database (BvD August 2010 release) and Petrov democratisation variable: dem1 is a 1991-2001 time invariant variable; dem2 is a $2000-2004$ time invariant variable; dem3 is a 2001-2006 time invariant variable. These are merged to create a time variant democratisation variables on the 1996-2008 time span,

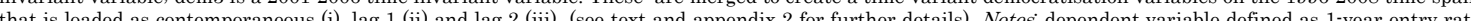
that is loaded as contemporaneous (i), lag 1 (ii) and lag 2 (iii) (see text and appendix 2 for further details). Notes. dependent variable defined as 1 -year entry rate in the region, sector and year. 'Natural entry' rate defined as 1-year entry in European Union as 1998-2003 average within the relevant 2-digit NACE rev. 1.1 sector. Coefficients reported as marginal effect on truncated expected value at 0 (lower bound) and 1 (upper bound). All regressions include 88 Macro Regions, 62 Sector and 13 Time dummies. The null hypothesis of joint zero coefficients for the $D r, D i$ and $D t$, respectively, is always rejected at $1 \%$ level ( $\mathrm{Y}^{* * *}$.

Therefore, the regressions reported in Tables 3 and 4 test a similar hypothesis with a different set of political indicators. We report three columns; using the Petrov index contemporaneously, and with one and two years of lag. The results are initially counterintuitive. The coefficient on the interactive term is always negative, which implies that, the deviation from natural entry rates is higher in regions in which higher levels of political competition and transparency are greater. Turning to Table 4, which replicates the previous experiment controlling for firm size, we find an explanation. The direction of the impact of the degree of democratization on entry rates depends on the size of the entrant. Greater democracy acts to stimulate entry by small sized firms, reducing the deviation of entry by sector from their natural rate. 
However, greater democratization greatly reduces entry for medium and especially the large firms. This effect is so large in scale that it offsets the increases in entry with greater democracy in the small size class. These results hold for all three specifications of lags.

TABLE 4.-DEMOCRATISATION DETERMINANTS OF ENTRY: SIZE EFFECT

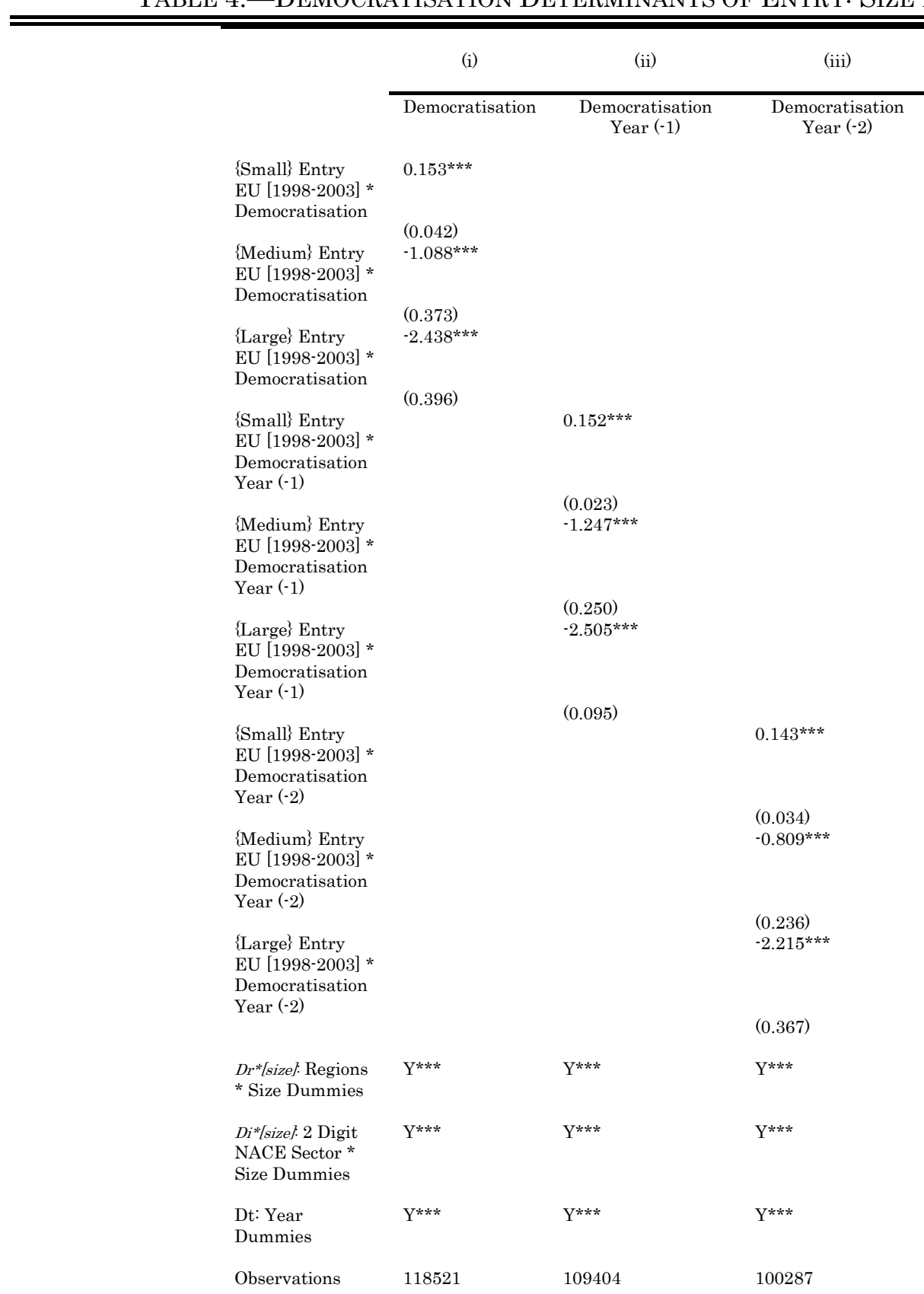

Tobit Regression, coefficients and bootstrapped standard errors in parentheses: ${ }^{* * *} \mathrm{p}<0.01,{ }^{* *} \mathrm{p}<0.05,{ }^{*} \mathrm{p}<0.1$. Source: Authors' computations on ORBIS Database (BvD August 2010 release) and Petrov democratisation variable: dem1 is a 1991-2001 time invariant variable; dem2 is a $2000-2004$ time invariant variable; dem3 is a 2001-2006 time invariant variable. These are merged to create a time variant democratisation variables on the 1996-2008 time span, that is loaded as contemporaneous (i), lag 1 (ii) and lag 2 (iii) (see text and appendix 2 for further details). Notes: dependent variable defined as 1-year entry rate in the region, sector, size and year. 'Natural entry' rate defined as 1-year entry in European Union as 1998-2003 average within the relevant 2-digit NACE rev. 1.1 sector. Coefficients reported as marginal effect on truncated expected value at 0 (lower bound) and 1 (upper bound). All regressions include 88 Macro Regions, 62 Sector and 13 Time dummies. The null hypothesis of joint zero coefficients for the $D r^{*}[$ size $], D^{*}[$ size $] i$ and $D t$, respectively, is always rejected at $1 \%$ level (Y***). 


\section{CONCLUSIONS}

Applying the methodology developed by Rajan and Zingales (1998) and exploited by Klapper, Laeven, and Rajan (2006), we analyze the relationship between political predictability of the policy environment, the quality of institutions proxied by the degree of democratisation and new firm entry. Similar to Aghion, Fally, and Scarpetta (2007), we exploit the within-region differences between industries, firm size and time using a regional longitudinal dataset. Russia offers some dimensions of a natural quasi-experiment to explore this issue, because the economy is huge and regionally diverse and there is great heterogeneity in institutions and the policy environment. Moreover, given the transition process which is occurring at an uneven rate across Russian regions, there is the possibility of identifying exogenous political change which signals adjustments to the political environment. One of the most important contributions of the paper is therefore to develop a longitudinal dataset of regional political change in Russia, to explore whether this influences the entry process.

Our work provides an interesting development of the existing literature on entry and the institutional environment. First, we circumvent the problem encountered in traditional cross country studies of approximating institutions by country specific dummies. Our approach reduces the number of alternative explanations by analysing entry in the context of a single national entity. By investigating cross-regional variation in entry and the political environment, we are able to control for differences in for example macro-economic policy that may influence results in cross-country studies. Furthermore, by the use of a new dataset on political change, we have been able to allay concerns about endogeneity of institutional indicators. Finally, we extend studies of institutional impact on entry, pioneered by Djankov, La Porta, Lopez-de- 
Silanes, and Shleifer (2002). While the latter explored the impact of formal institutions on entry, this approach was criticised for failing to capture the impact of informal practices, which may mitigate the impact of formal regulation of entry, Aidis and Adachi (2007). Our work addresses this criticism by taking account of informal institutions and demonstrates that institutional environment as a whole has a considerable influence on entry rates.

One might expect that entry rates in an emerging market with a legacy of central planning might be relatively high, Estrin (2002). This is because to reap economies of information, planners tended to rely on relatively few firms so that when the market was suddenly introduced, the number of firms in each sector was relatively small relative to demand. More generally, the low numbers of firms in developing economies suggest that entry rates might be quite high, Tybout (2000), and this is the finding in for example Roberts and Tybout (1996). Indeed, we confirm that Russian entry rates are not low by international standards though we include small firms in our dataset. However, we note a declining trend in entry rates over time.

We go on to show that the deviation of entry rates from their natural sectoral rate across regions is exacerbated by political instability. The impact of gubernatorial change in reducing entry rates is large, and increases over time between one and two years. These results are robust to alternative specifications, for example controlling for categories of firm size. We conclude that in Russia, entry is promoted by predictability of the regional political arena, which stems from political continuity, be it in the form of a re-election of an incumbent or election of a candidate from the same political elite.

We also use a dataset from secondary sources to consider the character of the regional political regime with respect to democratic institutions. This has the advantage of 
indicating the direction of the political change implied by the results above, but the analysis is less robust in terms of reverse causality. Nonetheless the findings are suggestive. In regions which are more transparent and democratic, entry rates of small sized firms are increased. However, this effect is more than offset by the negative impact of greater democracy for entry by medium and large firms. We offer two related explanations. First, the difference in the effect of business environment on entry of small firms compared to larger ones may indicate predatory behaviour of the state. Big firms are more likely to be targeted by unscrupulous politicians as they are more noticeable and generate higher rent. This 'grabbing hand' view of the state would predict that larger firms are disproportionally affected by a change of politicians at the very top of regional administration and therefore are more affected by uncertainty and political competition. A somewhat different explanation hinges on the necessity of forging close links with the top politicians in order to set up firms and prosper as a business. Again, large and medium firms are more likely to rely on personal networks with top politicians then small firms. Therefore, disruption of such networks through governor change is more likely to impact on entry of larger firms and leave smaller businesses relatively unaffected.

Finally, we find that entry is most significantly affected two years after governor change. This is in line with the view that entry is a long term project, which spans a long time between the initial decision to enter and actual establishment of a firm. Although the legal registration of a firm may be completed in a year, creating a going concern may take much longer. Therefore, in the initial years after governor change we continue to see the entry of firms for which resources were likely to have been committed previously. 


\section{REFERENCES}

Acemoglu, D., Johnson S. (2005), Institutions as a Fundamental Cause of LongRun Growth, in Aghion P., S. Durlauf (eds.), Handbook of Economic Growth, Volume 1, Elsevier.

Aghion, P., Blundell R., Griffith R., Howitt P., and Prantl S. (2004), Entry and Productivity Growth: Evidence form Microlevel Panel Data, Journal of the European Economic Association, vol. 2 (2-3), 265-276.

Aghion, P., Bolton P. (1987), Contracts as a Barrier to Entry, American Economic Review, vol.77 (3), 388-401.

Aghion, P., Fally T., Scarpetta S. (2007), Credit Constraints as Barrier to Entry and Post-Entry Growth of Firms, Economic Policy, pp. 731-779.

Aidis, R., Adachi Y. (2007), Russia: Firm Entry and Survival Barriers, Economic Systems, vol. 31 (4), 391-411.

Aidis, R., Estrin S., Mickiewicz T. (2008), Institutions and Entrepreneurship Development in Russia: A Comparative Perspective, Journal of Business Venturing, vol. 23 (6), 656-672.

Audretsch, D.B., Acs. Z.J. (1991), Innovation as a Means of Entry: An Overview, in Geroski P.A., Schwalbach J. (eds.), Entry and Market Contestability, Blackwell, UK.

Bain, J. (1949), A Note on Pricing in Monopoly and Oligopoly, American Economic Review, vol. 39 (2), 448-64.

Bain, J. (1968), Industrial Organization, Wiley: New York.

Benerjee, A. V., Ghatak M. (2005) Institutions and Economic Performance, Economics of Transition, vol. 13 (3), 421-425.

Berkowitz, D., DeJong D. (2005a), Entrepreneurship and Post-Socialist Growth, Oxford Bulletin of Economics and Statistics, vol. 67 (1), 25-46.

Berkowitz, D., DeJong D. (2005b), Economic Fragmentation in Russia: The Influence of International Trade and Initial Conditions, Economics of Governance, vol. 6 (3), 253-268.

Bartelsman, E., Haltiwanger, J. and S. Scarpetta (2004), Microeconomic evidence of creative destruction in industrial and developing countries, World Bank Policy Research Working Paper 3464.

Bartelsman, E., Haltiwanger, J. and F. Schivardi (2003), Comparative Analysis of Firm Demographics and Survival: Micro-Level Evidence for the OECD Countries, OECD Economics Department Working Papers no. 348, OECD Publishing. 
Bertrand, M., Kramarz F. (2002), Does Entry Regulation Hinder Job Creation? Evidence from the French Retail Industry, The Quarterly Journal of Economics, vol. 117 (4), 13691413.

Brown, J. D., Earle J.S. (2006), The Microeconomics of Creating Productive Jobs: a Synthesis of Firm-Level Studies in Transition Economies, World Bank Policy Research Working Paper 3886, April 2006, The World Bank.

Brown, D., Earle J.S., Gehlbach S. (2009), Helping Hand or Grabbing Hand? State Bureaucracy and Privatization Effectiveness, American Political Science Review, vol. 203 (2), 264-283.

Campos, N., Iootty M. (2007), Institutional Barriers to Firm Entry and Exit: Case Study Evidence from the Brazilian Textiles and Electronics Industries, Economic Systems, vol. 31 (4), 346-363.

Carlton, D. W. (2004), Why Barriers to Entry are Barriers to Understanding, American Economic Association: Papers and Proceedings, vol. 94 (2), 466-470.

Casson, M. (2005), Entrepreneurship and the Theory of the Firm, Journal of Economic Behaviour and Organisation, vol. 58 (2), 327-348.

Caves, R. (1998), Industrial Organization and New Findings on the Turnover and Mobility of Firms, Journal of Economic Literature, vol. 36 (4), 1947-1982.

Centre for Economic and Financial Research at New Economic School (2007), Monitoring the Administrative Barriers to Small Business Development in Russia, Round 6, http://www.cefir.ru/index.php?l=eng \\&id=260.

Chamberlain, E. (1956), The Theory of Monopolistic Competition, Harvard University Press

Ciccone A., Papaionnaou E. (2007), Red Tape and Delayed Entry, Journal of European Economic Association, vol. 5 (2-3), 444-458.

De Soto, H. (1990), The Other Path: The Invisible Revolution in the Third World, Harper: New York.

Dixit, A. (1979), A Model of Duopoly Suggesting a Theory of Entry Barriers, Bell Journal of Economics, vol. 10 (1), 20-32.

Dixit, A. (1980), The Role of Investment in Entry Deterrence, The Economic Journal, vol. 90 (357), pp. 95-106.

Djankov, S., La Porta R. Lopez-de-Silanes F., Shleifer A. (2002), The Regulation of Entry, Quarterly Journal of Economics, vol. 117 (1), 1-37.

Dunne, T., Roberts, M.J., Samuelson L. (1989), The Growth and Failure of U.S. Manufacturing Plants, Quarterly Journal of Economics, vol. 104 (4), 671-698.

Dun and Bradstreet (2000), US entry rate 1998-99 data, http://www.dnb.com/us 
Estrin, Saul (2002),Competition and corporate governance in transition, Journal of Economic Perspectives, 16 (1). pp. 101-124.

Estrin, S., Campos N. (2007), Entry and Barriers to Entry in Emerging Markets," Economic Systems, vol. 31 (4), 343-345.

Estrin, S., Prevezer M. (2010), A survey on institutions and new firm entry: How and why do entry rates differ in emerging markets?, Economic Systems, vol. 34 (3), September , pp. 289-308

European Bank for Reconstruction and Development (2005), The Performance of Firms in Transition, Transition Report, Chapter 4, pp. 82-92.

Federal State Statistics Service (2006), Data on Russian Regions, Federal State Statistics Service, Moscow.

Friedman, E., Johnson, S., Kaufmann, D., Zoido-Lobaton P. (2000), Dodging the Grabbing Hand: the Determinants of Unofficial Activity in 69 Countries, Journal of Public Economics, vol. 76 (3), 459-493.

Frye, T., Shleifer A. (1997), The Invisible Hand and the Grabbing Hand, American Economic Review, vol. 87 (2), 354-358.

Geroski, P. A. (1991), Entry and Market Contestability: An International Comparison, Basil Blackwell: Oxford

Geroski, P. A. (1995), What Do We Know About Entry?, International Journal of Industrial Organisation, vol. 13 (4), pp. 421-440.

Gilbert, R.J. (1989), Mobility Barriers and the Value of Incumbency, in Schmalensee R. and Willig R.D. (eds.), Handbook of Industrial Organization, Volume 1, Elsevier Science Publishers, North-Holland: Amsterdam, pp. 47-535.

Gilbert, R.J. and X. Vives, (1986), Entry Deterrence and the Free Rider Problem, Review of Economic Studies, vol. 53 (1), 71-83.

Hausman R., Rodrik D. (2003), Economic Development as Self-Discovery, Journal of Development Economics, 72 (2), 603-633.

Jovanovic, B. (1982), Selection and the Evolution of Industry, Econometrica, vol. 50 (3), 649-670.

Klapper, L., Laeven L., Rajan R. (2006), Entry Regulation as a Barrier to Entrepreneurship, Journal of Financial Economics, vol. 82 (3), 591-629.

Konitzer A. (2005), Voting for Russia's Governors: Regional Elections and Accountability under Yeltsin and Putin, The John Hopkins University Press: Baltimore.

Konitzer, A., Wegren S. (2006), Federalism and Political Recentralisation in the Russian Federation: United Russia As the Party of Power, Publius, vol. 36 (4), 503-522.

Krivka, Algirdas. (2006), The Experience of Russia in Reforming Tax System: Achievements, Problems and Perspectives, Management, nr. 2 (11), pp. 73-77. 
Lambert-Mogiliansky, A., Sonin K., Zhuravskaya E. (2007), Are Russian Commercial Courts biased? Evidence From a Bankruptcy Law Transplant, Journal of Comparative Economics, vol. 35 (2), 254-277.

Mau, V., Yanovskiy K. (2002) Political and Legal Factors of Economic Growth in Russian Regions, Post-Communist Economies, 14 ( 3), 321-339.

McFaul, Michael A., Petrov Nikolai, Ryabov Andrei (2004), Between Dictatorship and Democracy: Russian Post-communist Political Reform, Washington, DC: Carnegie Endowment for International Peace.

Moraski B. (2006), Elections by Design: Parties and Patronage in Russia's Regions, Northern Illinois University Press: DeKalb.

Moses J. (2002), Political-Economic Elites and Russian Regional Elections 1999-2000: Democratic Tendencies in Kaliningrad, Perm and Volgograd, Europe-Asia Studies, vol. 54 (6), 905-931.

North, D.C. (1991), Institutions, Journal of Economic Perspectives, vol. 5 (1), 97-112.

OECD (2002), Trade Politics in Russia: The Role of Local and Regional Governments, OECD: Paris.

Orr, D. (1974), The Determinants of Entry: A Study of the Canadian Manufacturing Industries, Review of Economics and Statistics, vol. 56, 58-65.

Orttung, R. (2004), Business and Politics in the Russian Regions, Problems of PostCommunism, vol. 51 (2), pp. 48-60.

Popov, V. (2001), Reform Strategies and Economic Performance of Russia's Regions, World Development, vol. 29 (5), 865-886.

Rajan, R. G., Zingales L. (1998), Financial Dependence and Growth, American Economic Review, vol. 88 (3), 559-586.

Rodrik, D., Subramanian A., Trebbi F. (2004), Institutions Rule: The Primacy of Institutions over Geography and Integration in Economic Development, Journal of Economic Growth, 9, pp: 131-165.

Ross, C. (2003), Putin's Federal Reforms and the Consolidation of Federalism in Russia: One Step Forward, Two Steps Back, Communist and Post-Communist Studies, vol. 36 (1), 29-47.

Rutkowski, J., Scarpetta S. (2005), Enhancing Job Opportunities: Eastern Europe and the Former Soviet Union, The World Bank: Washington.

Shleifer, A., Treisman D. (2005), A Normal Country: Russia After Communism, Journal of Economic Perspectives, vol. 19 (1), 151-174.

Shleifer, A., Vishny R. W. (1993), Corruption, Quarterly Journal of Economics, vol. 108 (3), 599-617. 
Stigler, G. (1968), The Organization of Industry, Homewoof, IL: Irwin.

Treisman, D. (2002), Russia Renewed?, Foreign Affairs, vol. 81 (6), 58-72.

Tybout, J. R. (2000), Manufacturing Firms in Developing Countries: How Well Do They Do, and Why, Journal of Economic Literature, vol. 38 (1), 11-44. 


\section{DATA APPENDIX 1: ENTRY RATES SUMMARY STATISTICS}

TABLE A1.1-ENTRY RATES: MEAN AND SD BY SIZE AND TIME LAG

\begin{tabular}{|c|c|c|c|c|c|c|c|c|c|c|c|c|c|c|c|c|}
\hline & \multicolumn{2}{|c|}{ All $1 \mathrm{y}$} & \multicolumn{2}{|c|}{ All 2 yrs } & \multicolumn{2}{|c|}{ Small 1 yr } & \multicolumn{2}{|c|}{ Small 2 yrs } & \multicolumn{2}{|c|}{ Medium 1 yr } & \multicolumn{2}{|c|}{ Medium 2 yrs } & \multicolumn{2}{|c|}{ Big 1 yr } & \multicolumn{2}{|c|}{ Big 2 yrs } \\
\hline & Mean & SD & Mean & SD & Mean & $\mathrm{SD}$ & Mean & SD & Mean & SD & Mean & $\mathrm{SD}$ & Mean & $\mathrm{SD}$ & Mean & SD \\
\hline 1996 & $11.9 \%$ & $14.8 \%$ & $25.0 \%$ & $21.2 \%$ & $10.6 \%$ & $17.8 \%$ & $21.7 \%$ & $24.9 \%$ & $8.2 \%$ & $20.0 \%$ & $17.8 \%$ & $28.9 \%$ & $6.7 \%$ & $18.5 \%$ & $13.6 \%$ & $26.4 \%$ \\
\hline 1997 & $10.9 \%$ & $13.8 \%$ & $21.2 \%$ & $19.1 \%$ & $10.1 \%$ & $16.7 \%$ & $19.5 \%$ & $23.2 \%$ & $7.6 \%$ & $18.9 \%$ & $15.1 \%$ & $26.4 \%$ & $5.3 \%$ & $16.9 \%$ & $11.7 \%$ & $24.0 \%$ \\
\hline 1998 & $10.5 \%$ & $13.8 \%$ & $20.0 \%$ & $18.5 \%$ & $10.0 \%$ & $16.3 \%$ & $18.9 \%$ & $22.3 \%$ & $7.4 \%$ & $18.4 \%$ & $14.4 \%$ & $25.3 \%$ & $5.4 \%$ & $16.3 \%$ & $10.4 \%$ & $22.8 \%$ \\
\hline 1999 & $11.2 \%$ & $13.7 \%$ & $20.4 \%$ & $18.4 \%$ & $11.7 \%$ & $17.7 \%$ & $20.4 \%$ & $22.6 \%$ & $7.5 \%$ & $18.5 \%$ & $14.2 \%$ & $24.9 \%$ & $4.8 \%$ & $15.4 \%$ & $9.9 \%$ & $21.9 \%$ \\
\hline 2000 & $12.3 \%$ & $14.5 \%$ & $21.9 \%$ & $18.8 \%$ & $12.8 \%$ & $18.2 \%$ & $22.9 \%$ & $23.6 \%$ & $8.0 \%$ & $19.3 \%$ & $14.9 \%$ & $25.6 \%$ & $5.1 \%$ & $15.8 \%$ & $9.6 \%$ & $21.6 \%$ \\
\hline 2001 & $10.2 \%$ & $12.4 \%$ & $21.0 \%$ & $18.0 \%$ & $13.4 \%$ & $17.3 \%$ & $24.3 \%$ & $23.0 \%$ & $10.5 \%$ & $21.6 \%$ & $17.8 \%$ & $27.2 \%$ & $5.6 \%$ & $16.5 \%$ & $10.3 \%$ & $22.2 \%$ \\
\hline 2002 & $11.3 \%$ & $13.0 \%$ & $20.2 \%$ & $16.9 \%$ & $13.1 \%$ & $16.7 \%$ & $24.5 \%$ & $22.2 \%$ & $7.7 \%$ & $17.2 \%$ & $17.3 \%$ & $26.1 \%$ & $4.7 \%$ & $14.9 \%$ & $10.0 \%$ & $21.6 \%$ \\
\hline 2003 & $12.8 \%$ & $13.3 \%$ & $22.5 \%$ & $17.3 \%$ & $14.4 \%$ & $17.4 \%$ & $25.6 \%$ & $22.0 \%$ & $8.9 \%$ & $18.3 \%$ & $15.9 \%$ & $23.9 \%$ & $4.1 \%$ & $13.6 \%$ & $8.5 \%$ & $19.8 \%$ \\
\hline 2004 & $6.5 \%$ & $9.1 \%$ & $18.3 \%$ & $15.5 \%$ & $13.1 \%$ & $15.4 \%$ & $25.5 \%$ & $21.2 \%$ & $8.4 \%$ & $17.3 \%$ & $16.5 \%$ & $24.0 \%$ & $4.4 \%$ & $14.5 \%$ & $8.3 \%$ & $19.4 \%$ \\
\hline 2005 & $6.1 \%$ & $9.1 \%$ & $12.1 \%$ & $12.9 \%$ & $11.4 \%$ & $14.1 \%$ & $22.8 \%$ & $19.5 \%$ & $8.6 \%$ & $18.2 \%$ & $16.3 \%$ & $23.9 \%$ & $4.4 \%$ & $13.9 \%$ & $8.5 \%$ & $19.8 \%$ \\
\hline 2006 & $6.1 \%$ & $9.1 \%$ & $11.7 \%$ & $13.1 \%$ & $11.6 \%$ & $14.2 \%$ & $21.5 \%$ & $19.0 \%$ & $5.8 \%$ & $14.1 \%$ & $13.8 \%$ & $22.2 \%$ & $2.7 \%$ & $10.6 \%$ & $7.0 \%$ & $17.3 \%$ \\
\hline 2007 & $4.2 \%$ & $6.9 \%$ & $10.0 \%$ & $11.7 \%$ & $8.7 \%$ & $12.2 \%$ & $19.2 \%$ & $17.9 \%$ & $3.5 \%$ & $11.3 \%$ & $9.1 \%$ & $17.6 \%$ & $1.8 \%$ & $8.4 \%$ & $4.5 \%$ & $13.4 \%$ \\
\hline 2008 & $2.4 \%$ & $4.7 \%$ & $6.5 \%$ & $8.7 \%$ & $5.5 \%$ & $9.0 \%$ & $13.7 \%$ & $14.9 \%$ & $0.8 \%$ & $5.2 \%$ & $4.3 \%$ & $12.3 \%$ & $0.4 \%$ & $3.9 \%$ & $2.2 \%$ & $9.2 \%$ \\
\hline Total & $9.0 \%$ & $12.3 \%$ & $17.8 \%$ & $17.4 \%$ & $11.3 \%$ & $16.0 \%$ & $21.6 \%$ & $21.6 \%$ & $7.2 \%$ & $17.5 \%$ & $14.4 \%$ & $24.3 \%$ & $4.3 \%$ & $14.4 \%$ & $8.8 \%$ & $20.6 \%$ \\
\hline
\end{tabular}

Source ORBIS database (BvD copyright), August 2010 release for Russian Federation. The overall sample exploits all the firms declaring the date of incorporation, i.e. 85\% of the observations from ORBIS (see also footnote 7 and 14 in the text). The size level database is build by splitting the overall firm sample in three parts according to their size category. Entry rates are computed within separate categories. Finally the three parts are pooled back together in a single size-level database. Some firms do report date of incorporation but not size and therefore are part of the overall sample database. Only firms reporting date of incorporation and size are included in the size level data. 
TABLE A1.2.-ENTRY RATES: MEAN AND SD BY REGION (1996-2008)

\begin{tabular}{|c|c|c|c|c|}
\hline & Mean & $\mathrm{SD}$ & Mean & $\mathrm{SD}$ \\
\hline Belgorod region & $9.8 \%$ & $10.3 \%$ & $19.0 \%$ & $15.0 \%$ \\
\hline Bryansk region & $9.9 \%$ & $11.0 \%$ & $19.0 \%$ & $15.3 \%$ \\
\hline Vladimir region & $8.6 \%$ & $9.9 \%$ & $17.3 \%$ & $14.5 \%$ \\
\hline Voronezh region & $8.7 \%$ & $7.7 \%$ & $17.2 \%$ & $11.3 \%$ \\
\hline Ivanovo region & $9.1 \%$ & $10.4 \%$ & $17.9 \%$ & $15.2 \%$ \\
\hline Kaluga region & $8.5 \%$ & $8.9 \%$ & $17.1 \%$ & $13.2 \%$ \\
\hline Kostroma region & $8.0 \%$ & $9.4 \%$ & $15.9 \%$ & $13.9 \%$ \\
\hline Kursk region & $7.5 \%$ & $11.9 \%$ & $15.0 \%$ & $16.5 \%$ \\
\hline Lipetsk region & $7.8 \%$ & $11.7 \%$ & $15.5 \%$ & $16.7 \%$ \\
\hline Moscow region & $9.6 \%$ & $7.4 \%$ & $19.2 \%$ & $11.7 \%$ \\
\hline Orel region & $8.7 \%$ & $10.8 \%$ & $17.7 \%$ & $16.3 \%$ \\
\hline Ryazan region & $8.0 \%$ & $9.9 \%$ & $16.2 \%$ & $15.0 \%$ \\
\hline Smolensk region & $8.5 \%$ & $9.6 \%$ & $16.7 \%$ & $13.9 \%$ \\
\hline Tambov region & $8.7 \%$ & $13.7 \%$ & $17.0 \%$ & $18.9 \%$ \\
\hline Tver region & $8.5 \%$ & $9.8 \%$ & $17.1 \%$ & $14.7 \%$ \\
\hline Tula region & $7.8 \%$ & $6.7 \%$ & $15.5 \%$ & $10.4 \%$ \\
\hline Yaroslavl region & $8.4 \%$ & $8.4 \%$ & $16.4 \%$ & $12.4 \%$ \\
\hline Moscow & $11.8 \%$ & $7.7 \%$ & $23.7 \%$ & $13.1 \%$ \\
\hline Republic of Karelia & $8.3 \%$ & $12.2 \%$ & $16.7 \%$ & $17.4 \%$ \\
\hline Komi Republic & $9.1 \%$ & $12.4 \%$ & $18.3 \%$ & $17.4 \%$ \\
\hline Arkhangelsk region & $8.2 \%$ & $10.7 \%$ & $16.6 \%$ & $15.3 \%$ \\
\hline Nenets AO not in the list & $7.4 \%$ & $19.1 \%$ & $15.0 \%$ & $26.5 \%$ \\
\hline Vologoda region & $10.1 \%$ & $11.6 \%$ & $19.8 \%$ & $16.2 \%$ \\
\hline Kaliningrad region & $8.7 \%$ & $9.3 \%$ & $17.6 \%$ & $14.6 \%$ \\
\hline Leningrad region & $8.4 \%$ & $9.0 \%$ & $17.0 \%$ & $14.1 \%$ \\
\hline Murmansk region & $7.4 \%$ & $9.6 \%$ & $15.1 \%$ & $14.4 \%$ \\
\hline Novgorod region & $8.1 \%$ & $10.7 \%$ & $16.2 \%$ & $15.6 \%$ \\
\hline Pskov region & $9.1 \%$ & $11.4 \%$ & $18.0 \%$ & $16.2 \%$ \\
\hline Saint Petersburg & $9.0 \%$ & $7.8 \%$ & $18.0 \%$ & $12.8 \%$ \\
\hline Republic of Adygeya & $9.0 \%$ & $13.3 \%$ & $17.5 \%$ & $18.4 \%$ \\
\hline Republic of Dagestan & $5.8 \%$ & $9.6 \%$ & $12.4 \%$ & $14.9 \%$ \\
\hline Republic of Ingooshetia & $9.2 \%$ & $16.2 \%$ & $18.7 \%$ & $22.7 \%$ \\
\hline Kabardino Balkarian Republic & $5.5 \%$ & $10.2 \%$ & $11.4 \%$ & $14.9 \%$ \\
\hline Republic of Kalmykia & $8.7 \%$ & $15.7 \%$ & $18.2 \%$ & $23.8 \%$ \\
\hline Karachayevo Cherkessian Republic & $6.5 \%$ & $13.2 \%$ & $13.0 \%$ & $18.1 \%$ \\
\hline Republic of North Ossetia Altania & $5.4 \%$ & $8.5 \%$ & $11.3 \%$ & $13.5 \%$ \\
\hline Chechen Republic* & $16.6 \%$ & $25.8 \%$ & $29.9 \%$ & $33.7 \%$ \\
\hline Krasnodar Territory & $7.9 \%$ & $7.3 \%$ & $16.0 \%$ & $11.0 \%$ \\
\hline Stavropol Territory & $8.8 \%$ & $9.8 \%$ & $17.7 \%$ & $14.4 \%$ \\
\hline Astrakhan region & $8.2 \%$ & $10.2 \%$ & $16.3 \%$ & $14.7 \%$ \\
\hline Volgograd region & $10.3 \%$ & $9.8 \%$ & $20.2 \%$ & $14.2 \%$ \\
\hline Rostov region & $8.5 \%$ & $8.1 \%$ & $17.2 \%$ & $12.2 \%$ \\
\hline Republic of Bashkorstan & $9.6 \%$ & $9.6 \%$ & $19.3 \%$ & $14.2 \%$ \\
\hline Republic of Marij El & $8.6 \%$ & $11.9 \%$ & $17.0 \%$ & $16.8 \%$ \\
\hline
\end{tabular}




\begin{tabular}{|c|c|c|c|c|}
\hline Republic of Mordovia & $8.2 \%$ & $11.6 \%$ & $16.1 \%$ & $15.9 \%$ \\
\hline Republic of Tatarstan & $9.3 \%$ & $8.3 \%$ & $18.8 \%$ & $12.5 \%$ \\
\hline Udmurtian Republic & $8.1 \%$ & $7.5 \%$ & $16.0 \%$ & $11.4 \%$ \\
\hline Chuvashi Republic & $10.2 \%$ & $12.0 \%$ & $19.9 \%$ & $16.7 \%$ \\
\hline Kirov region & $9.4 \%$ & $11.3 \%$ & $18.4 \%$ & $16.4 \%$ \\
\hline Nizhnii Novgorod region & $8.6 \%$ & $9.1 \%$ & $17.3 \%$ & $13.1 \%$ \\
\hline Orenburg region & $8.9 \%$ & $10.3 \%$ & $17.7 \%$ & $14.5 \%$ \\
\hline Penza region & $9.5 \%$ & $11.1 \%$ & $18.4 \%$ & $15.3 \%$ \\
\hline Perm region & $10.8 \%$ & $9.5 \%$ & $21.1 \%$ & $13.5 \%$ \\
\hline Komi Permiatsk AO not in the list & $6.7 \%$ & $17.0 \%$ & $13.0 \%$ & $23.2 \%$ \\
\hline Samara region & $10.4 \%$ & $6.9 \%$ & $20.8 \%$ & $11.4 \%$ \\
\hline Saratov region & $8.7 \%$ & $9.3 \%$ & $17.4 \%$ & $14.2 \%$ \\
\hline Ulyanovsk region & $10.5 \%$ & $9.7 \%$ & $20.6 \%$ & $14.1 \%$ \\
\hline Kurgan region & $7.6 \%$ & $9.8 \%$ & $15.4 \%$ & $14.6 \%$ \\
\hline Sverdlovsk region & $9.3 \%$ & $9.2 \%$ & $19.0 \%$ & $14.9 \%$ \\
\hline Tyumen region & $8.4 \%$ & $9.6 \%$ & $17.1 \%$ & $14.6 \%$ \\
\hline Khanty Mansijsk Autonomous District & $9.0 \%$ & $12.5 \%$ & $18.0 \%$ & $17.8 \%$ \\
\hline Yamalo Nenets Autonomous District & $9.1 \%$ & $13.9 \%$ & $18.1 \%$ & $19.4 \%$ \\
\hline Chelyabinsk region & $8.6 \%$ & $7.0 \%$ & $17.5 \%$ & $11.6 \%$ \\
\hline Altai Republic & $12.2 \%$ & $19.6 \%$ & $23.2 \%$ & $26.3 \%$ \\
\hline Republic of Buryatia & $9.3 \%$ & $15.0 \%$ & $18.6 \%$ & $20.4 \%$ \\
\hline Republic of Tuva & $9.4 \%$ & $17.3 \%$ & $18.5 \%$ & $23.0 \%$ \\
\hline Republic of Khakassia & $9.4 \%$ & $14.3 \%$ & $18.3 \%$ & $19.2 \%$ \\
\hline Altayski Krai Region & $8.7 \%$ & $10.0 \%$ & $17.4 \%$ & $14.3 \%$ \\
\hline Krasnoyarsk Territory & $9.1 \%$ & $7.8 \%$ & $18.2 \%$ & $11.6 \%$ \\
\hline Taimyr (DolganoNenets) Autonomous District & $8.2 \%$ & $17.5 \%$ & $16.6 \%$ & $24.2 \%$ \\
\hline Evenk Autonomous District & $8.7 \%$ & $22.4 \%$ & $16.4 \%$ & $30.0 \%$ \\
\hline Irkutsk region & $9.0 \%$ & $8.7 \%$ & $17.9 \%$ & $12.3 \%$ \\
\hline Ust Ordyn Buryat Autonomous District & $8.3 \%$ & $18.3 \%$ & $16.4 \%$ & $25.3 \%$ \\
\hline Kemerovo region & $11.2 \%$ & $10.9 \%$ & $21.8 \%$ & $15.5 \%$ \\
\hline Novosibirsk region & $10.6 \%$ & $9.7 \%$ & $20.8 \%$ & $14.1 \%$ \\
\hline Omsk region & $10.5 \%$ & $11.7 \%$ & $20.4 \%$ & $16.5 \%$ \\
\hline Tomsk region & $9.7 \%$ & $9.8 \%$ & $19.0 \%$ & $13.6 \%$ \\
\hline Chita region & $7.3 \%$ & $12.3 \%$ & $14.5 \%$ & $17.1 \%$ \\
\hline Aginsk Buryat Autonomous District & $7.9 \%$ & $18.6 \%$ & $15.3 \%$ & $25.1 \%$ \\
\hline Republic of Sakha (Yakutia) & $9.7 \%$ & $11.4 \%$ & $19.7 \%$ & $17.0 \%$ \\
\hline Primorie Territory & $9.2 \%$ & $9.4 \%$ & $18.7 \%$ & $14.1 \%$ \\
\hline Khabarovsk Territory & $9.4 \%$ & $10.0 \%$ & $18.9 \%$ & $15.2 \%$ \\
\hline Amur region & $9.3 \%$ & $15.1 \%$ & $18.0 \%$ & $20.5 \%$ \\
\hline Kamchatka region & $7.2 \%$ & $9.6 \%$ & $14.9 \%$ & $14.4 \%$ \\
\hline Koryak Autonomous District & $6.8 \%$ & $17.1 \%$ & $14.3 \%$ & $25.4 \%$ \\
\hline Magadan region & $7.7 \%$ & $12.9 \%$ & $15.7 \%$ & $18.4 \%$ \\
\hline Sakhalin region & $8.4 \%$ & $11.0 \%$ & $16.6 \%$ & $16.1 \%$ \\
\hline Jewish Autonomous District & $10.6 \%$ & $18.2 \%$ & $20.6 \%$ & $24.7 \%$ \\
\hline Chukotka Autonomous District & $7.0 \%$ & $16.4 \%$ & $14.8 \%$ & $23.2 \%$ \\
\hline Total & $9.0 \%$ & $11.9 \%$ & $17.8 \%$ & $17.0 \%$ \\
\hline
\end{tabular}




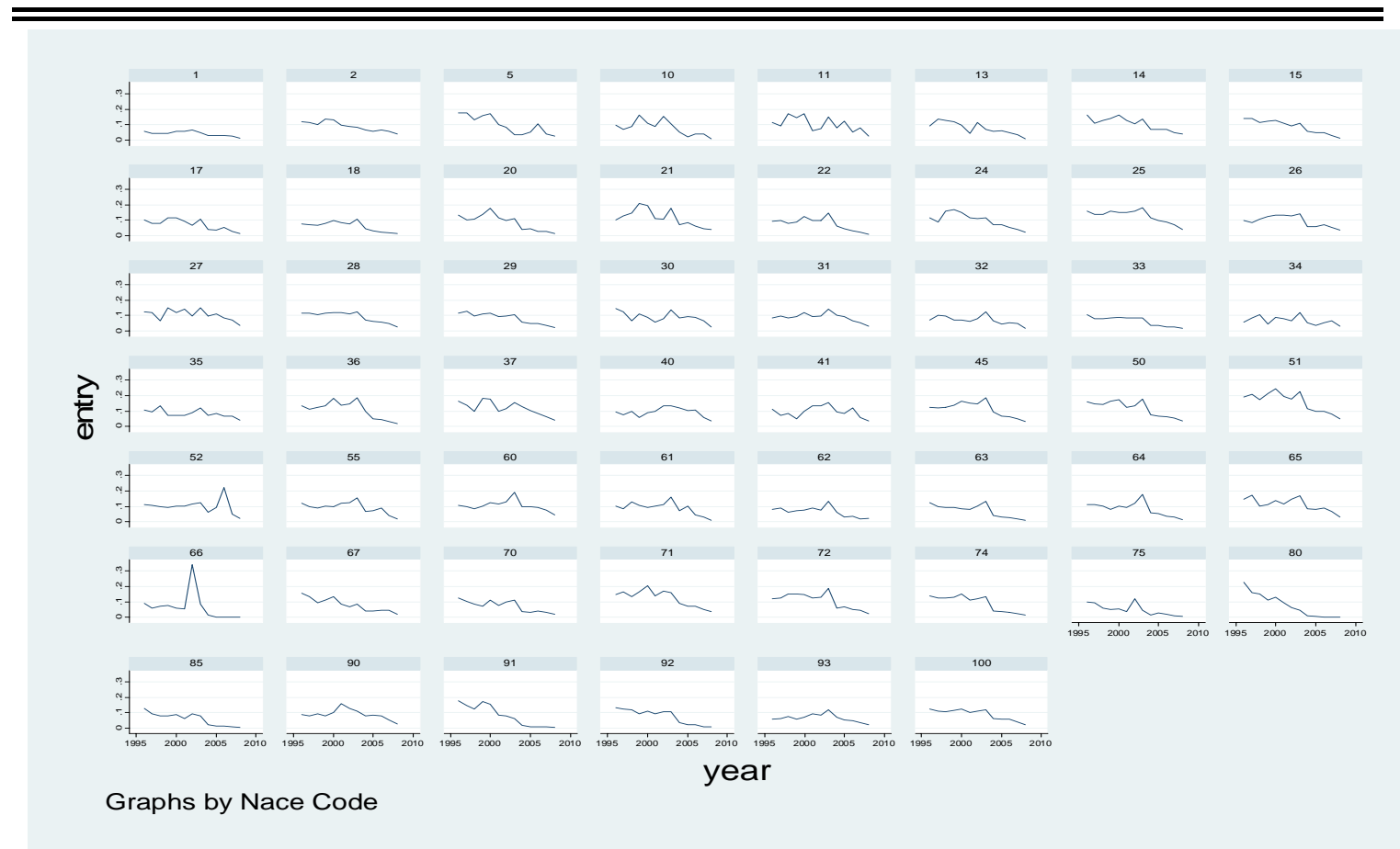

GRAPH A1.2-ENTRY RATES: STANDARD DEVIATIONBY SECTOR (1996-2008)

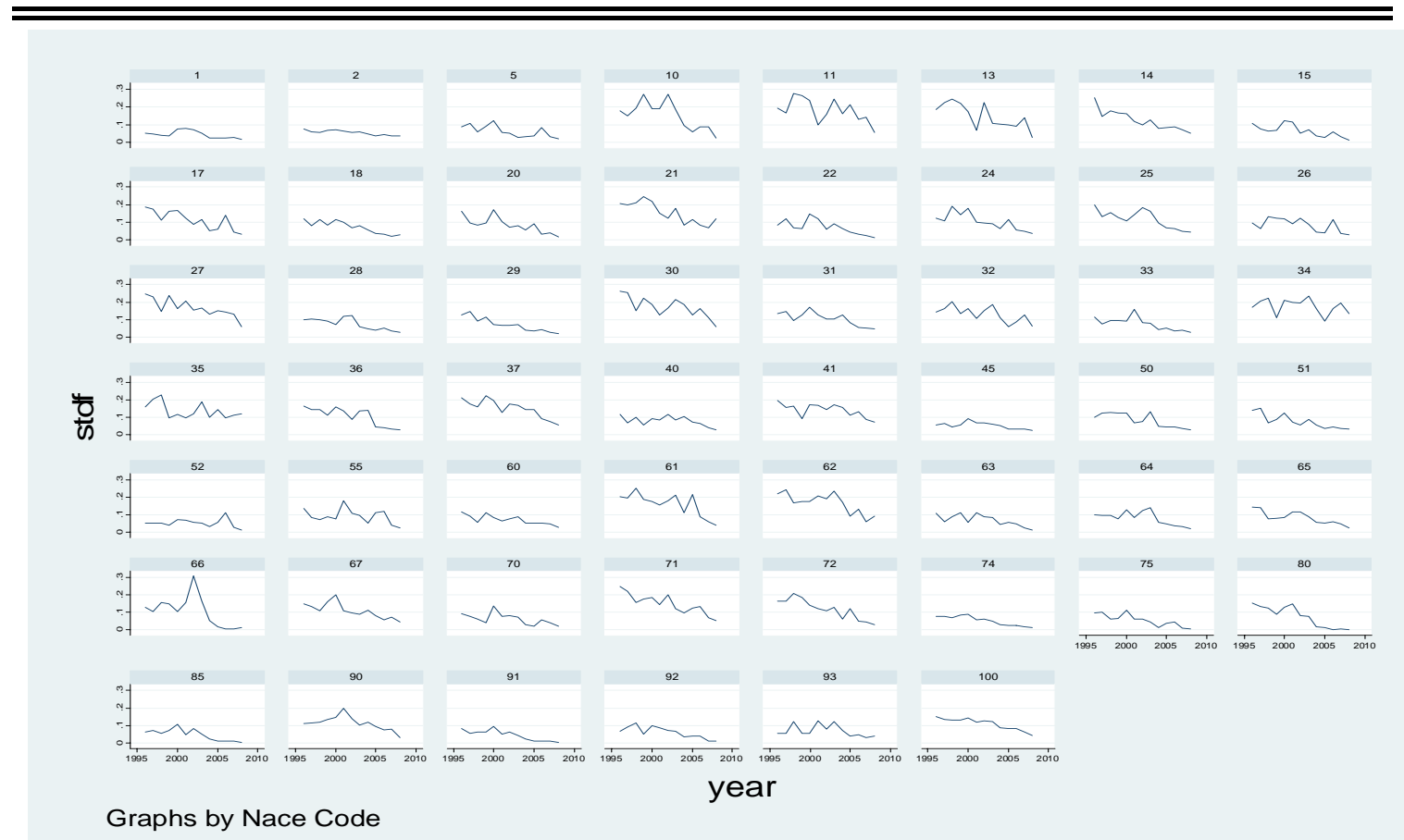

Source ORBIS database (BvD copyright), August 2010 release for Russian Federation. NACE rev 1.1 ISIC Excluding; agriculture, mining, utility, financial intermediation and public administration. Sector "100" is the Total aggregated entry. Graph A1 reports means and Graph A2 reports SD. 


\section{Data Appendix 2: A Closer look at Democratisation and the Political TURNOVERS VARIABLES}

\section{$\underline{\text { Regional political and economic openness dataset }}$}

Measures of regional political and economic openness were used to estimate transparency and predictability of regional political and economic processes based on a number of indicators. This data was sourced from Nikolay Petrov and Aleksei Titkov at the Carnegie Moscow Center ${ }^{22}$. The dataset includes 10 sub-indicators, which together provide an assessment of political and economic openness in each region. In our estimations, we use both a cumulative variable for democratisation (composed out of 9 sub-indicators, i.e. excluding economic liberalisation), and the 10 sub-indicators separately. The sub-indicators give respectively an account of political factors (political openness, elections, pluralism, regional political structure), economic factors (economic liberalization, corruption), and civil-society and social factors (media, civil society, elites, local self-government).

Openness is an indicator of the openness or foreclosure of political life (with respect to transparency and inclusion into national processes), whereas elections captures the quality of political competition in regional elections at all levels (barriers to participation, use of administrative resources in favour of incumbents, political interference). Pluralism measures the presence and number of stable parties, factions and coalitions in legislative assemblies. Regional political structure is an overall indicator of the quality of political and judicial processes in a region, of respect for civil rights, as well as an assessment of the respective weight of elections and appointments.

Economic liberalization captures the degree of privatization as well as the quality of regional legislative and legal practice in regard to local enterprises, whereas corruption 
measures the degree of overlap between political and economic elites and the number of corruption scandals in the period observed.

Finally, media measures the degree of media independence, the role taken by the media in regional political life and potential interference by politicians. Civil society accounts for the number of NGOs, referendums and forms of unsanctioned public activity. Elites stands for the diversity, reproduction and turnover of regional elites and their capacity to coordinate their interests and avoid political breakdown and instability. Local self government measures the presence of elected bodies of local self-government and their activeness and influence.

The cumulative variable for democratisation is divided by Petrov in three time spans, within which it is time invariant: 1991-2001 (called dem1); 2000-2004 (called dem2); 2001-2006 (called dem3). In our data base ‘dem1' 'dem2' and 'dem3' are merged over time to create a time variant democratisation variables on the $1996-2008$ time span, that is then loaded as contemporaneous, lagged 1 year or lagged 2 years in the regressions.

\section{Governor turnover dataset}

In order to capture the uncertainty associated with governor turnover and the consequential shift in regional policies, we constructed a dataset measuring political change at the governor level. The dataset covers the period $1996-2009$ and reports instances when the incumbent governor's term in the office expired (whether he or she stood for re-election or re-appointment), instances of governor change (again, whether through elections or re-appointment) and quality of such change. While for the period 1996 - 2004 we report elections, for 2005 - 2009 we report appointments, as governors 
were directly appointed by the president from September 2004 onwards, following a constitutional change after the hostage crisis in Beslan. ${ }^{23}$

The dataset further specifies if a newly elected or appointed governor shares the same political background as his predecessor, or comes from a different political group, thus controlling for a change in regional political elites. We finally constructed a set of cumulative variables, permitting us to control for the frequency and overall amount of political change in each region.

Data on governor change, elections and appointments have been collected from regional websites, a website on Russian administrative divisions (http://rulers.org/russdiv.html), and the Russian version of Wikipedia, using several sources for each case to check for consistency. To measure the degree of uncertainty associated with possible continuity or discontinuity of current economic and political practice we distinguished between governors from the same political elite and governors from the oppositional elite. Governors were assumed to belong to the same political elite if they came from the predecessor's political circle (i.e. friend, relative or deputy governor) or came from a similar professional background, such security forces or, in some instances, came from the same political party. A candidate was assumed to come from an oppositional elite group if he did not belong to the governor's political circle. To determine whether a new

\footnotetext{
${ }^{23}$ Russian political system has undergone several changes that have affected stability of regional institutions. Prior to 1996 local regional authorities were appointed by Yeltsin. In 1996 popular elections replaced presidential appointments, opening doors to political contestation among local as well as national political elites vying to influence local political and economic processes. In 2005 the political system made a full circle as Russia yet again set on a course towards higher centralised control. President Putin announced introduction of gubernatorial appointments by the president, which from 2005 onwards replaced popular elections for gubernatorial post, previously held in the regions. The new process of presidential appointments involves three procedural steps. First, the potential candidates for gubernatorial seat are selected by presidential envoy to the federal district and submitted to the president. Alternatively, the party with majority seats in regional parliament can also make its recommendations. Second, the president nominates his preferred candidate and informs the regional assembly of his choice. In the third step, regional assembly needs to approve the nominee by a majority of votes in order for the presidential candidate to take up his seat.
} 
governor had the same political background as his predecessor, we checked the personal background of each governor, using web resources on personal profiles such as www.lenta.ru and www.russiaprofile.org.

As we are interested in the change of the governing elite in a specific region, it was not always sufficient to look for political affiliation, as two subsequent governors might both belong to the same party (e.g. United Russia), but defend different regional agendas or economic interests, and belong to different clans or groupings. If cases were not clear, we consulted additional information from articles in the regional and national press, as well as from publications on the political economy of Russia's regions, e.g. Moses (2002), Konitzer (2005), Moraski (2006).

From 2005 to 2008, a number of regions were merged or added to other, larger regions (with 6 entities having lost their autonomy to date). However, this does not significantly affect the sample, as these regions were often very small. Finally, for Chechnya we adopted official Russian data on government changes. Although Chechnya is of course a special case, we opted for three elite changes in 1996/1997, 2000 and 2003, as it could be argued that from 2003 onwards the elites in control belonged to the Kadyrov family. In any case, taking Chechnya out of the sample does not significantly alter our results. 
TABLE A2.1.- Political AND Economic Openness: MEAN \& SD By REGiON (1991-2006)

Belgorod region

Bryansk region

Vladimir region

Voronezh region

Ivanovo region

Kaluga region

Kostroma region

Kursk region

Lipetsk region

Moscow region

Orel region

Ryazan region

Smolensk region

Tambov region

Tver region

Tula region

Yaroslavl region

Moscow

Republic of Karelia

Komi Republic

Arkhangelsk region

Nenets AO not in the list

Vologoda region

Kaliningrad region

Leningrad region

Murmansk region

Novgorod region

Pskov region

Saint Petersburg

Republic of Adygeya

Republic of Dagestan

Republic of Ingooshetia

Kabardino Balkarian Republic

Republic of Kalmykia

Karachayevo Cherkessian Republic

Republic of North Ossetia Altania

Chechen Republic*

Krasnodar Territory

Stavropol Territory

Astrakhan region

Volgograd region

Rostov region

Republic of Bashkorstan dem 1

1991 - 2001

Mean

2,8

2,8

2,9

2,5

2,9

2,9

3,1

2,1

2,7

3

2,2

2,7

2,7

2,6

2,8

2,6

3,7

2,9

4,1

2,7

3,7

3,7

3,2

3,4

3,2

3

3

2,7

4,5

2,2

2,4

1,5

1,7

1,4

1,9

n.a.

2,6

2,5

2,8

3,4

2,4

1,8

0,32

0,32

0,48

0,52

0,42

0,52

0,67

0,67

0,67

0,42

0,97

0,63

\section{0}

1,33

0,85

0,63

0,97

0,53

0,48

0,52

0,52

0,32

0,7

0,53

0,42 $\begin{array}{cc}\text { dem2 } & \text { dem3 } \\ 2000-2004 & 2001-2006\end{array}$

Mean SD Mean SD

$0,42 \quad 2,5 \quad 0,53 \quad 2,5 \quad 0,53$

$\begin{array}{lllll}0,42 & 2,8 & 0,42 & 2,7 & 0,48\end{array}$

$\begin{array}{lllll}0,32 & 3,4 & 0,52 & 3,5 & 0,53\end{array}$

$\begin{array}{lllll}0,53 & 2,0 & 0,32 & 3,2 & 0,63\end{array}$

$\begin{array}{lllll}0,32 & 2,7 & 0,48 & 2,9 & 0,57\end{array}$

$\begin{array}{lllll}0,32 & 3,1 & 0,32 & 3,3 & 0,48\end{array}$

3

2,2

0

2,9

0,57

$0,42 \quad 2,2 \quad 0,42$

$0,52 \quad 2,8 \quad 0,42$

0,48

2,6

0,71

2,8

0,79

0,42

2,4

0,52

2,6

0,52

$\begin{array}{llll}2,8 & 0,42 & 3 & 0,67\end{array}$

2,7

0,48

2,7

0,48

2,8

0,42

$2,8 \quad 0,42$

3

0,47

3,5

0,71

2,8

0,42

0,32

3,8

0

0,48

3,1

0,88

0,57

3

0,63

0,57

4,1

0,7

4

0,94

3,6

0,7

3,5

0,47

3,6

0,7

3,5

0,53

3,7

0,48

4,1

0,53

2,9

0,32

2,9

0,57

3,5

0,71

3,6

0,32

3,5

0,53

3,5

0,84

3,1

0,32

3,3

0,53

3,5

0,71

3,3

0,48

3,4

0,52

3,6

0,48

4,1

0,88

0,48

4

0,52

2,3

0,85

2,5

0,82

2,5

0,48

2,5

0,53

1,7

0,48

1,7

0,85

1,7

0,47

1,8

0,48

2,3

0,48

2,2

2,4

0,42

1,9

0,32

2

n.a.

n.a.

2,7

0,48

2,8

2,7

0,48

3,2

0,48

2,7

0,42

3

3,5

0,52

0,52

2,5

$0,42 \quad 2$

0,53

0,92

1,8

2

0,47 


\begin{tabular}{|c|c|c|c|c|c|c|}
\hline Republic of Marij El & 2,8 & 0,42 & 2,7 & 0,48 & 2,6 & 0,52 \\
\hline Republic of Mordovia & 2,1 & 0,32 & 2 & 0 & 2 & 0 \\
\hline Republic of Tatarstan & 2,3 & 0,82 & 2,3 & 0,48 & 2,5 & 0,53 \\
\hline Udmurtian Republic & 3,3 & 0,67 & 3 & 0,47 & 3 & 0 \\
\hline Chuvashi Republic & 3,1 & 0,57 & 3,3 & 0,67 & 3,2 & 0,42 \\
\hline Kirov region & 2,9 & 0,32 & 2,8 & 0,42 & 2,9 & 0,32 \\
\hline Nizhnii Novgorod region & 4 & 0,67 & 4,1 & 0,57 & 3,8 & 0,42 \\
\hline Orenburg region & 2,6 & 0,52 & 3 & 0 & 3 & 0 \\
\hline Penza region & 2,5 & 0,53 & 2,7 & 0,48 & 2,8 & 0,42 \\
\hline Perm region & 4,1 & 0,32 & 4,1 & 0,57 & 4,3 & 0,67 \\
\hline Komi Permiatsk AO & 2,6 & 0,52 & 2,9 & 0,32 & - & - \\
\hline Samara region & 3,7 & 0,82 & 4,2 & 0,63 & 4,5 & 0,71 \\
\hline Saratov region & 2,6 & 0,52 & 2,6 & 0,52 & 2,8 & 0,63 \\
\hline Ulyanovsk region & 2,4 & 0,84 & 2,5 & 0,53 & 2,9 & 0,32 \\
\hline Kurgan region & 2,4 & 0,52 & 2,4 & 0,52 & 2,4 & 0,52 \\
\hline Sverdlovsk region & 4,3 & 1,06 & 4,5 & 0,71 & 4,2 & 0,79 \\
\hline Tyumen region & 3 & 0,47 & 3,4 & 0,52 & 3,3 & 0,48 \\
\hline Khanty Mansijsk AO & 3,2 & 0,63 & 3,3 & 0,48 & 3,4 & 0,52 \\
\hline Yamalo Nenets AO & 2,8 & 0,42 & 2,9 & 0,57 & 3 & 0,47 \\
\hline Chelyabinsk region & 3,4 & 0,52 & 3,6 & 0,52 & 3,6 & 0,7 \\
\hline Altai Republic & 2,8 & 0,42 & 2,7 & 0,48 & 3 & 0,47 \\
\hline Republic of Buryatia & 3 & 0 & 3 & 0 & 3,1 & 0,32 \\
\hline Republic of Tuva & 1,9 & 0,57 & 1,7 & 0,48 & 1,8 & 0,42 \\
\hline Republic of Khakassia & 2,9 & 0,57 & 2,3 & 0,48 & 2,4 & 0,52 \\
\hline Altayski Krai Region & 2,5 & 0,53 & 2,7 & 0,67 & 3,5 & 0,53 \\
\hline Krasnoyarsk Territory & 3,3 & 0,67 & 4,1 & 0,57 & 4,3 & 0,48 \\
\hline Taimyr (DolganoNenets) AO & 2,4 & 0,52 & 2,6 & 0,52 & 2,6 & 0,52 \\
\hline Evenk Autonomous District & 1,9 & 0,57 & 2 & 0,47 & 2,1 & 0,32 \\
\hline Irkutsk region & 3,7 & 0,48 & 3,6 & 0,52 & 4 & 0,67 \\
\hline Ust Ordyn Buryat AO & 1,9 & 0,57 & 2 & 0,47 & 2 & 0,67 \\
\hline Kemerovo region & 2,8 & 0,63 & 2,5 & 0,53 & 2,4 & 0,52 \\
\hline Novosibirsk region & 3,7 & 0,48 & 3,9 & 0,57 & 4 & 0,47 \\
\hline Omsk region & 2,9 & 0,32 & 2,9 & 0,32 & 3 & 0,47 \\
\hline Tomsk region & 2,9 & 0,32 & 3 & 0 & 3,3 & 0,67 \\
\hline Chita region & 2,5 & 0,53 & 2,6 & 0,52 & 2,7 & 0,48 \\
\hline Aginsk Buryat Autonomous District & 1,8 & 0,63 & 1,8 & 0,63 & 1,8 & 0,63 \\
\hline Republic of Sakha (Yakutia) & 2,1 & 0,57 & 2,8 & 0,42 & 2,7 & 0,48 \\
\hline Primorie Territory & 2,3 & 0,82 & 2,8 & 0,63 & 2,8 & 0,63 \\
\hline Khabarovsk Territory & 2,5 & 0,53 & 2,5 & 0,53 & 2,9 & 0,32 \\
\hline Amur region & 2,6 & 0,52 & 2,6 & 0,52 & 3 & 0,67 \\
\hline Kamchatka region & 2,9 & 0,57 & 2,9 & 0,74 & 3,2 & 0,79 \\
\hline Koryak Autonomous District & 2,4 & 0,7 & 2,2 & 0,63 & 2,4 & 0,84 \\
\hline Magadan region & 2,6 & 0,52 & 2,9 & 0,32 & 3,1 & 0,32 \\
\hline Sakhalin region & 3,3 & 0,48 & 3,3 & 0,48 & 3,5 & 0,53 \\
\hline Jewish Autonomous District & 2,3 & 0,48 & 2,3 & 0,48 & 2,3 & 0,48 \\
\hline Chukotka Autonomous District & 1,7 & 0,48 & 2 & 0,67 & 1,8 & 0,63 \\
\hline Total & 2,75 & 0,55 & 2,86 & 0,49 & 2,97 & 0,53 \\
\hline
\end{tabular}




\begin{tabular}{|c|c|c|c|c|}
\hline & ELECT. & $\begin{array}{l}\text { Gov. } \\
\text { Chan. }\end{array}$ & OPP. & $\begin{array}{l}\text { POL. } \\
\text { Disc. }\end{array}$ \\
\hline Belgorod region & 3 & 0 & 0 & 3 \\
\hline Bryansk region & 4 & 2 & 1 & 7 \\
\hline Vladimir region & 3 & 1 & 1 & 5 \\
\hline Voronezh region & 4 & 3 & 3 & 10 \\
\hline Ivanovo region & 3 & 3 & 2 & 8 \\
\hline Kaluga region & 4 & 2 & 0 & 6 \\
\hline Kostroma region & 4 & 2 & 2 & 8 \\
\hline Kursk region & 3 & 2 & 2 & 7 \\
\hline Lipetsk region & 3 & 1 & 1 & 5 \\
\hline Moscow region & 3 & 1 & 1 & 5 \\
\hline Orel region & 3 & 1 & 1 & 5 \\
\hline Ryazan region & 4 & 3 & 2 & 9 \\
\hline Smolensk region & 4 & 3 & 2 & 9 \\
\hline Tambov region & 3 & 1 & 1 & 5 \\
\hline Tver region & 3 & 1 & 1 & 5 \\
\hline Tula region & 3 & 2 & 2 & 7 \\
\hline Yaroslavl region & 3 & 1 & 1 & 5 \\
\hline Moscow & 4 & 0 & 0 & 4 \\
\hline Republic of Karelia & 3 & 1 & 1 & 5 \\
\hline Komi Republic & 3 & 1 & 1 & 5 \\
\hline Arkhangelsk region & 4 & 3 & 2 & 9 \\
\hline Nenets AO & 5 & 4 & 3 & 12 \\
\hline Vologoda region & 4 & 1 & 0 & 5 \\
\hline Kaliningrad region & 3 & 3 & 3 & 9 \\
\hline Leningrad region & 5 & 2 & 2 & 9 \\
\hline Murmansk region & 5 & 2 & 2 & 9 \\
\hline Novgorod region & 3 & 1 & 1 & 5 \\
\hline Pskov region & 4 & 3 & 3 & 10 \\
\hline Saint Petersburg & 4 & 2 & 2 & 8 \\
\hline Republic of Adygeya & 3 & 2 & 2 & 7 \\
\hline Republic of Dagestan & 1 & 1 & 0 & 2 \\
\hline Republic of Ingooshetia & 4 & 3 & 2 & 9 \\
\hline Kabardino Balkarian Republic & 3 & 1 & 1 & 5 \\
\hline Republic of Kalmykia & 2 & 0 & 0 & 2 \\
\hline Karachayevo Cherkessian Republic & 3 & 2 & 2 & 8 \\
\hline Republic of North Ossetia Altania & 3 & 2 & 1 & 6 \\
\hline Chechen Republic* & 6 & 6 & 3 & 15 \\
\hline Krasnodar Territory & 4 & 2 & 1 & 7 \\
\hline Stavropol Territory & 4 & 2 & 1 & 7 \\
\hline Astrakhan region & 4 & 1 & 0 & 5 \\
\hline Volgograd region & 4 & 2 & 2 & 8 \\
\hline Rostov region & 3 & 0 & 0 & 3 \\
\hline Republic of Bashkorstan & 3 & 0 & 0 & 3 \\
\hline Republic of Marij El & 4 & 2 & 2 & 8 \\
\hline
\end{tabular}




\begin{tabular}{|c|c|c|c|c|}
\hline Republic of Mordovia & 3 & 0 & 0 & 3 \\
\hline Republic of Tatarstan & 3 & 0 & 0 & 3 \\
\hline Udmurtian Republic & 3 & 0 & 0 & 3 \\
\hline Chuvashi Republic & 3 & 0 & 0 & 3 \\
\hline Kirov region & 4 & 3 & 2 & 9 \\
\hline Nizhnii Novgorod region & 3 & 3 & 2 & 8 \\
\hline Orenburg region & 3 & 1 & 1 & 5 \\
\hline Penza region & 3 & 1 & 1 & 5 \\
\hline Perm region & 4 & 3 & 0 & 7 \\
\hline Komi Permiatsk AO & 2 & 0 & 0 & 2 \\
\hline Samara region & 4 & 1 & 0 & 5 \\
\hline Saratov region & 3 & 2 & 2 & 7 \\
\hline Ulyanovsk region & 4 & 2 & 2 & 8 \\
\hline Kurgan region & 4 & 1 & 0 & 5 \\
\hline Sverdlovsk region & 4 & 1 & 1 & 6 \\
\hline Tyumen region & 3 & 2 & 1 & 6 \\
\hline Khanty Mansijsk Autonomous District & 3 & 0 & 0 & 3 \\
\hline Yamalo Nenets Autonomous District & 3 & 0 & 0 & 3 \\
\hline Chelyabinsk region & 3 & 1 & 1 & 5 \\
\hline Altai Republic & 3 & 3 & 1 & 7 \\
\hline Republic of Buryatia & 2 & 1 & 1 & 4 \\
\hline Republic of Tuva & 3 & 2 & 0 & 5 \\
\hline Republic of Khakassia & 4 & 2 & 2 & 8 \\
\hline Altayski Krai Region & 4 & 3 & 2 & 9 \\
\hline Krasnoyarsk Territory & 3 & 2 & 2 & 7 \\
\hline Taimyr (DolganoNenets) Autonomous District & 3 & 2 & 2 & 7 \\
\hline Evenk Autonomous District & 3 & 3 & 3 & 9 \\
\hline Irkutsk region & 5 & 4 & 1 & 10 \\
\hline Ust Ordyn Buryat Autonomous District & 4 & 2 & 2 & 8 \\
\hline Kemerovo region & 3 & 2 & 0 & 5 \\
\hline Novosibirsk region & 3 & 1 & 0 & 4 \\
\hline Omsk region & 3 & 0 & 0 & 3 \\
\hline Tomsk region & 3 & 0 & 0 & 3 \\
\hline Chita region & 4 & 2 & 0 & 6 \\
\hline Aginsk Buryat Autonomous District & 4 & 2 & 2 & 8 \\
\hline Republic of Sakha (Yakutia) & 3 & 1 & 0 & 4 \\
\hline Primorie Territory & 3 & 1 & 1 & 5 \\
\hline Khabarovsk Territory & 4 & 1 & 0 & 5 \\
\hline Amur region & 5 & 5 & 2 & 12 \\
\hline Kamchatka region & 4 & 2 & 0 & 6 \\
\hline Koryak Autonomous District & 3 & 2 & 1 & 6 \\
\hline Magadan region & 5 & 2 & 1 & 8 \\
\hline Sakhalin region & 3 & 2 & 1 & 6 \\
\hline Jewish Autonomous District & 2 & 0 & 0 & 2 \\
\hline Chukotka Autonomous District & 4 & 2 & 1 & 7 \\
\hline Total & 3,45 & 1,66 & 1,1 & 6,22 \\
\hline
\end{tabular}




\section{Data APPEndix 3: Unit Root Tests For The EnTRy RATE PANEL}

TABLE A3.1-UNit RoOT TESTS FOR PANEL: $P$-VALUES

\begin{tabular}{|c|c|c|c|c|}
\hline & $(1)$ & $(2)$ & (3) & (4) \\
\hline & \multicolumn{2}{|c|}{ Region, Sector, $\operatorname{Year}(r, i, t)$} & \multicolumn{2}{|c|}{$\begin{array}{l}\text { Region, Sector, Year and Size } \\
(r, i, t, s) \\
\text { Number of panels } 9151,13 \text { years }\end{array}$} \\
\hline & Ho: Unit Root & $\begin{array}{l}\text { Ho: Unit Root } \\
\text { ( time trend) }\end{array}$ & Ho: Unit Root & $\begin{array}{l}\text { Ho: Unit Root } \\
\text { (time trend) }\end{array}$ \\
\hline $\begin{array}{l}\text { A) Levin-Lin-Chu } \\
\text { test }\end{array}$ & {$\left[0.000^{* * * *}\right]$} & {$\left[0.000^{* * * *}\right]$} & {$\left[0.000^{* * * *}\right]$} & {$\left[0.000^{* * * *}\right]$} \\
\hline $\begin{array}{l}\text { B) Harris- } \\
\text { Tzavalis test }\end{array}$ & {$\left[0.000^{* * * *}\right]$} & {$\left[0.000^{* * * *}\right]$} & {$\left[0.000^{* * * *}\right]$} & {$\left[0.000^{* * * *}\right]$} \\
\hline C) Breitung test & {$\left[0.000^{* * * * *}\right]$} & {$\left[0.000^{* * * *}\right]$} & {$\left[0.000^{* * * *}\right]$} & {$\left[0.000^{* * * *}\right]$} \\
\hline $\begin{array}{l}\text { D) Fisher Test } \\
\text { (ADF } 3 \text { lags) }\end{array}$ & {$\left[0.000^{* * * *}\right]$} & {$[0.000 * * * *]$} & {$\left[0.000^{* * * *}\right]$} & {$\left[0.000^{* * * *}\right]$} \\
\hline
\end{tabular}

Tests for unit roots in panel datasets: A) The Levin-Lin-Chu (2002); B) Harris-Tzavalis (1999); C) Breitung (2000; Breitung and Das 2005); D) Fisher-type (Choi 2001). The null hypothesis is that the panels contain a unit root: $P$-values in square brackets. All the tests reject the null hypothesis at 1\% level for the region, sector and year panel "entry rates" series (columns 1 and $2-$ when controlling also for time trend-) as well as the region, sector, size and year "entry rates" series (columns 3 and 4, -when controlling also for time trend-). 